Discussion Paper No. 02-36

\title{
Relative Specialisation of EU Regions: An Econometric Analysis of Sectoral Gross Fixed Capital Formation
}

Claudia Stirböck

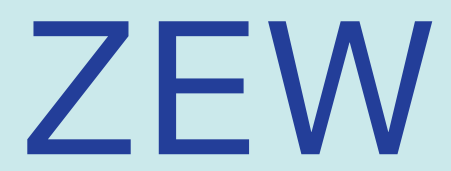

Zentrum für Europäische Wirtschaftsforschung $\mathrm{GmbH}$

Centre for European Economic Research 
Discussion Paper No. 02-36

\title{
Relative Specialisation of EU Regions: An Econometric Analysis of Sectoral Gross Fixed Capital Formation
}

\author{
Claudia Stirböck
}

Download this ZEW Discussion Paper from our ftp server:

ftp://ftp.zew.de/pub/zew-docs/dp/dp0236.pdf

Die Discussion Papers dienen einer möglichst schnellen Verbreitung von neueren Forschungsarbeiten des ZEW. Die Beiträge liegen in alleiniger Verantwortung der Autoren und stellen nicht notwendigerweise die Meinung des ZEW dar.

Discussion Papers are intended to make results of ZEW research promptly available to other economists in order to encourage discussion and suggestions for revisions. The authors are solely responsible for the contents which do not necessarily represent the opinion of the ZEW. 


\section{Non-technical summary}

Since Krugman has assumed increasing core-periphery tendencies due to stronger sectoral concentration and regional specialisation in an economically integrated Europe, controversial discussions about this prediction have risen. However, the seminal study of Krugman comparing EU and US regional specialisation levels bases on mobile labour. But this high mobility of employees across US states contrasts sharply with the low mobility of labour across the EU. Results on specialisation tendencies for US states which base on employment data can therefore not simply be extended to EU countries or regions. Neglecting capital, though, might lead to disturbed results especially inside the EU where we face an increasing mobility of capital which is enforced by the EMU and financial market integration. This study therefore aims at identifying the economic determinants of the (un)even relative regional allocation of capital across industries (i.e. of regional investment specialisation levels). Its focus is on regional patterns as a profound analysis of regional, not only national, specialisation is still missing in recent research.

We consider regional data of the Eurostat REGIO database for the period between 1985 and 1994. Our focus is on NUTS 1- as well as on NUTS 2-regions - the latter being further disaggregated than the former. 56 NUTS 2- and 33-NUTS 1-regions from seven EU countries are included: France, Italy, Belgium, UK, Ireland, Denmark, and Luxembourg. The three latter, however, are mono-regional countries at NUTS 1- and NUTS 2-level, i.e. they are not disaggregated any further.

In order to capture the degree to which EU regions differ in their investment structures, indices of relative specialisation in terms of gross fixed capital formation are calculated for each region and each year. These relative investment specialisation indices are calculated with, first, the respective country and, second, EU chosen to be the reference economy. This means that sectoral investment shares are analysed in relation to the average national and to EU sectoral shares. Both perspectives lead to slightly different specialisation patterns, but the economic impacts identified in the econometric analyses are similar.

One important, but unsurprising feature that can be detected is the higher level of relative investment specialisation when regarding the more disaggregated NUTS 2-regions in comparison to the NUTS 1regions. In a descriptive analysis of the most and the least specialised regions within each country, we find higher specialised regions to perform worse in economic terms than lower specialised regions with respect to unemployment rate, number of patents, total regional GDP and total regional GFCF. The fact that the distribution of relative investment shares is more uneven in peripheral regions than in core regions while these regions are of poorer economic performance, already stresses the importance for the EU and its member countries not to neglect their focus on economic development of peripheral regions. Economic centres, especially the region of Bruxelles and the Île de France, are highly specialised as well. However, they demonstrate a large potential of high economic performance. As no causal relationship can be derived from this purely descriptive analysis, econometric analyses are conducted to test for the significance of potential determinants of the even or uneven relative allocation of investments across sectors within a region.

The theoretical basis for the empirical investigation of the determinants of sectoral concentration and regional specialisation of economic activity is vast. According to traditional trade theories, regional specialisation takes place in accordance with comparative advantages. The regional economics' polarisation theory stresses the potential cumulative causation of factor agglomeration in the centre and backwash effects for peripheral regions. Gravity models focus on centripetal forces such as market size and centrifugal forces such as transport costs and imperfect economic integration or liberalisation. Finally, the New Economic Geography finds transaction costs and economies of scale to explain among others the concentration of sectors in space. The core thus specialises in sectors with high economies of scale, the periphery in sectors with low or constant economies of scale.

We conduct GLS-estimates accounting for potential heteroscedasticity, instrumental-variable estimates accounting for possible endogeneity between specialisation and some of its determinants as well as a dynamic specification capturing possible first-order serial correlation effects. In addition, a logistic transformation was used to take account of the endogenous variable's restriction to the range between zero and one. All estimations lead to very similar results and provide evidence of a high importance of 
regional size, market size, the unemployment rate as well as the location in the centre or the periphery, population density, economic openness as well as capital market integration.

The bigger the size of a region is, the higher is the similarity of relative investments. Market size reflects the economic and demand potential of a region: The higher it is, the lower the relative specialisation in terms of investments tends to be. This is in contrast to the results of recent empirical studies on sectoral agglomeration which found market size to have an increasing influence on sectoral concentration across space. While firms tend to locate close to large markets and high demand (thus increasing sectoral concentration), regions with a large market seem to attract capital of all types of sectors with a rather even relative allocation (thus decreasing relative regional dissimilarities). This effect is counteracted by an apparently strong tendency towards high specialisation of central, economically most important regions who demonstrate to have a significantly higher level of relative investment specialisation. Equally, population density increases the specialisation level. The unemployment rate, finally, reflects negative economic performance of a region (not accounting for migration effects etc.). The higher it is, the stronger the relative regional specialisation turns out to be. The higher the distance of a region to the economic centre is, the less similar are its investment shares to EU average. Peripheral regions are thus stronger specialised in terms of relative investments than regions closer to the centre.

In addition, the impacts of economic openness and the influence of capital market integration are tested in separate estimates. Both indicators, however, are not available at the regional level, but only at the country level. They therefore might pick up country-specific effects in cross-sectional analyses. However, reliable results on the impact of liberalisation tendencies are gained in the pooled regressions when we are able to exploit the indicators' variation over time while efficiently controlling for country-specific effects. Both, the extent of capital market integration as well as economic openness consistently seem to have a significant increasing impact on relative specialisation levels of gross fixed capital formation.

Comparing results for NUTS 2- and the more aggregated NUTS 1-level, we find them to be similar. Only the regional size does not show a consistent significant influence on relative investment specialisation in NUTS 1-regions. As NUTS 1-regions are higher aggregated and usually consist of a number of NUTS 2-regions, their size differs much less than at NUTS 2-level. In addition, bigger regions are logically more diversified in relative investments than smaller regions. Thus, this result is not surprising.

By means of fixed effects estimates, there are only few significant impacts to be detected. The regionspecific constants all turn out to be highly significant in the fixed effects estimates. Consistently, we find only low explanatory power of further exogenous variables when controlling for region-specific effects. Regional characteristics like regional gross domestic product, the regional unemployment rate, regional size, the distance to the economic centre as well as the fact of being a central region thus seem to determine the respective level of specialisation to a large extent. The variation over time, though, is not explained by our regressions. In addition, the extent of market integration and thus of European integration seems to strengthen relative specialisation tendencies. 


\title{
Relative Specialisation of EU Regions: \\ An Econometric Analysis of Sectoral Gross Fixed Capital Formation
}

\author{
Claudia Stirboeck \\ Centre for European Economic Research (ZEW), Mannheim, Germany
}

May 2002

\begin{abstract}
This paper analyses the level of relative specialisation in terms of gross fixed capital formation in EU regions for the period between 1985 and 1994. Controlling for heteroscedasticity and potential endogeneity problems, we get consistent econometric results. Larger market and regional sizes diminish relative investment specialisation while a higher unemployment rate, population density, the fact of being a central region, the distance to the economic centre, and economic liberalisation increase its level. The variation of the specialisation level of one region over time, however, cannot be explained econometrically, it thus might underlie random disturbances.
\end{abstract}

Acknowledgements: Financial support of the Volkswagen-Stiftung within the project No. II/76547 is gratefully acknowledged. I would like to thank Laura Manthey, Paula Monotya, Jennifer Säwe, Elena Todorova, and especially Simone Giloth and Felix Morck for their enduring help in setting up the extensive regional data sets. I am also indebted to Herbert S. Buscher, Jürgen Kaehler and Michael Schröder for helpful comments. All remaining errors, however, are my own.

JEL classification: C30, F15, F2, R12

Keywords: Economic Geography, Regional Economics, Capital Allocation, Panel Data Analysis

\author{
Claudia Stirboeck \\ ZEW \\ PO Box 103443 \\ D-68034 Mannheim \\ Tel.: +49-621-1235-218 \\ Fax: +49-621-1235-223 \\ E-Mail: stirboeck@zew.de
}


Since Krugman (1991) has assumed increasing core-periphery tendencies due to stronger sectoral concentration and regional specialisation in an economically integrated Europe, controversial discussions about this prediction have risen. On the one hand, regional specialisation leads to a number of advantages. Firms or whole industries are able to benefit from economies of scale and intra-industrial linkages to a higher extent. On the other hand, the strong regional specialisation increases the potential risk of asymmetric shocks. Specialisation tendencies thus lead to the need of improved or new shock absorbing mechanisms on the national and even regional level, whereas inside EMU, monetary policy is centralised at the European level.

The seminal study of Krugman which confronts a lower level of relative specialisation in the EU with a higher one in the US is based on the analysis of mobile labour. But the high mobility of employees across US states contrasts sharply with that across the EU. Results on specialisation tendencies for US states which rely on employment data can therefore not simply be extended to EU countries or regions. In addition, inside the EU, an increasing mobility of capital enforced by European Monetary Union (EMU) and increased financial market integration can be observed. Due to the possible substitution of capital and labour as factors of production, the allocation of capital might reflect specialisation tendencies inside the EU which cannot be detected when restricting investigations to labour. However, up to now theoretical and descriptive analyses on regional specialisation and sectoral concentration focus on the production factor labour and are only rarely extended to production or trade data. The allocation of capital (investments and/or direct investments), however, has been neglected so far, but is subject of the analysis in Stirboeck (2001) and in European Commission (1999). In addition, a profound analysis of regional, not national, patterns of concentration or specialisation is still neglected in recent research. Exceptions are the studies of KalemliOzcan, Sorensen and Yosha (1999), Tirado, Paluzie and Pons (2000) as well as Stirboeck (2001).

The purpose of this study is to investigate the extent of regional specialisation inside the EU with the emphasis on the identification of important determinants of relative investment dissimilarities in EU regions and the impact of EU-integration on these regional developments. Determinants of regional specialisation and sectoral agglomeration tendencies are given by theoretical models of the international trade theory, regional economics as well as the new economic geography. In section II, these are summarised very shortly and the results of recent econometric analyses on the allocation of production and their empirical determinants are given.

Our econometric investigations on the determinants of the similar or dissimilar relative allocation of sectoral gross fixed capital formation (GFCF) within regions are then presented in section III. Data refer to the period 1985 to 1994 and to two different aggregation levels of the Eurostat nomenclature of territorial units (NUTS - Nomenclature des unités territoriales) of seven EU countries: NUTS 1- and NUTS 2-regions. NUTS 2-regions, the less aggregated geographical entities, are of particular importance as EU regional policy is implemented at NUTS 2-level. We run, for the 10 separate years, cross-sectional as well as pooled regressions by use of GLS- and IV-estimates as well as pooled regressions in logit terms. In addition, fixed effects (within) estimates and between estimates are conducted to control for different effects in the process of potentially dissimilar regional specialisation of EU regions. In these econometric analyses, we can detect that a higher market size as well as the size of a region decrease the regional level of relative investment specialisation while a higher rate of 
unemployment, number of patents as well as population density, the fact of being a central region, and the distance to the economic centre increase it. A higher level of economic openness or of capital market integration also leads to stronger structural dissimilarity.

\section{Explaining sectoral concentration and regional specialisation tendencies}

In traditional trade theory, regional specialisation is assumed to be in accordance with comparative advantages. Agglomeration tendencies such as a high density of population, capital or economic activity in only one regional area and a disequilibrium in economic developments are not to be expected. In a world with perfect capital mobility, investments should flow into those regions which are marked by low capital intensity in production, i.e. a relative abundance of labour, and thus the highest capital yields. Analogously, in case of perfect labour mobility, employees should migrate to the place where the highest wages can be gained. This process continues until an (international) equilibrium with identical factor prices is reached.

Gravity models in international economics explain economic flows between regions through gravitational and resistance forces such as market size or market potential, distance, barriers to international activity etc. The seminal gravity models of e.g. Tinbergen (1962) and Linnemann (1966) aimed at the determination of bilateral international trade flows. Due to their high power in the empirical explanation of bilateral flows, gravity models were extended to the analysis of e.g. direct investment flows, migration or tourism. The spatial concentration of e.g. investments can thus be the result of gravitational forces. These forces will gain importance when resistance forces, such as transport costs or imperfect integration, go down.

The new economic geography has sharply increased the importance of regional economic theory in the 1990s. It has induced a new wave of attention to concentration and specialisation patterns. However, regional economics have already provided a number of approaches to explain regional development patterns before the 1990s. The polarisation theory with such concepts as those of Myrdal (1957) and Hirschman (1958) have a great importance in this context. Myrdal (1957) stresses possible circular and cumulative agglomeration tendencies due to a "backwash-effect" which is unfortunate for peripheral regions. As qualified labour is marked by a higher mobility, they will move faster to exploit the core region's incentives and higher wages ${ }^{1}$. The approach of Hirschman (1958) bases on forward and backward linkages, i.e. advantages resulting from being close to the markets of procurement and to consumers. Again, these linkages lead to cumulative agglomeration in those regions already profiting from large markets. However, Hirschman assumes that in case of too large agglomeration, negative impacts prevent a further increase.

The new economic geography has gained a special focus of attention as according to these models, specialisation need not - like in the neo-classical world - to develop according to the comparative advantage of regions, but can be the result of historical conditions and macroeconomic (partly random) processes. Thus even similar regions can develop differently and the resulting patterns of specialisation are ex ante unpredictable. The new economic geography relies on some contributions of the new international trade theory giving up a number of assumptions which were prevalent in the neo-classical theory: existence of homogeneous products, identical production functions, perfect competition, and constant

\footnotetext{
${ }^{1}$ The existence of "spread effects", however, provides some positive spill-over effects for the peripheral regions. But Myrdal (1957) assumes them to be of minor importance.
} 
economies of scale. The incomplete equalisation of factor prices and spatial agglomerations can now be explained. Monopolistic competition is modelled by the use of specific consumer preferences: the preference for differentiated products (i.e. a "love of variety") ${ }^{2}$. Due to the existence of economies of scale at the level of plants (further increased by economies of localisation at the industrial level), firms do not produce at each single place of local demand. Instead, the production of each differentiated good is locally concentrated and close to large markets. The core thus specialises in economic activity underlying increasing economies of scale, the periphery in agriculture or industries with constant or low economies of scale.

In his core-periphery model, Krugman $(1991,1995,1996)$ considers one single production factor - labour - due to reasons of simplicity. He differentiates between mobile labour in the industrial sector and immobile labour in agriculture; hence according to Krugman (1991) agglomeration is measured by the concentration of labour force. In case of high transport costs, the allocation of production over space is rather persistent. Transport costs are a centrifugal force working against the spatial concentration of production. Decreasing transport costs, though, strengthen the centripetal force of economies of scale and might thus be a trigger for the concentration of production. This leads to a rise in labour demand and wages, and mobile labour will migrate to this region. This is the stronger the lower transport costs are which are finally reflected in higher real wages through lower prices. If transport costs are low enough, industrial workers might even concentrate in one region.

Some extensions and improvements of this seminal new economic geography model have been conducted in the last years - a survey of these developments can be found in Krugman (1998). An important extension to the standard model giving up the assumption of perfect labour mobility and hereby adapting better to intra-EU conditions is developed by Venables (1996) as well as Krugman and Venables (1995). In their theoretical framework, the concentration of production in the core can decrease again as soon as transport costs reach a critical low level. The reason for this is the dispersing influence of low wages in the periphery which is strong enough when transport costs are sufficiently low. Production in the periphery will then be expanded as immobile labour does not migrate to the core regions although these are marked by higher wages. This theoretical approach therefore predicts an inverse U-shaped development of concentration.

In addition to the imperfect labour mobility, another very important problem persists in the context of European integration. Not only is labour rather immobile across European borders and can even be assumed to be less mobile within EU countries than across US-states, also capital movements have become increasingly liberalised throughout the process of European monetary and economic integration ${ }^{3}$. However, spatial developments are explained by theoretical models that focus on labour and the effects of labour mobility. Krugman himself proposed to focus on mobile capital in future research in the framework of the new economic

\footnotetext{
${ }^{2}$ This kind of consumer preference has first been introduced by Dixit and Stiglitz (1977).

${ }^{3}$ All restrictions on long- and even short-term capital movements within EU are formally prohibited since the passing of the EU-Council directive 88/361/EEC in June 1988. However, a large number of exceptions to this directive have existed for very long. Even according to the IMF Annual Report on Exchange Restrictions 2000, some of them were still persisting in 1999 - the year of the instauration of EMU. In addition to these national administrative barriers, the segmentation of European capital markets also impeded the perfect liberalisation of capital movements. However, the European Common Market as well as the preparation and installation of EMU have exerted a great pressure on the implementation of perfect and unhindered capital mobility and have already improved market integration. For details, see e.g. the recent studies of Santillán, Bayle and Thygesen (2000), European Commission (2000) as well as Danthine, Giavazzi and von Thaden (2000).
} 
geography (Krugman and Venables, 1995) ${ }^{4}$. The empirical analyses of this paper are one step forward in this direction.

In spite of the growing number of theoretical and empirical studies on the location of industries, econometric studies explaining the extent of sectoral concentration and regional specialisation are still rare. Recent econometric studies investigating concentration tendencies of production across EU countries are Amiti (1999) and Haaland et al. (1999) as well as Tirado, Paluzie and Pons (2000) focusing on industrial shares in Spanish regions in the 19th century. The level of the industrial specialisation of regions of - among others - three EU countries, finally, is focussed on by Kalemli-Ozcan, Sorensen and Yosha (1999).

Amiti (1999) gets evidence for significant, positive effects of economies of scale and intermediate good intensities on the concentration of industries across five European countries in addition to mostly significant positive fixed industry and time effects which are not explained by the model. Fixed time effects have been increasing over time which according to the author might pick up trade liberalisation effects. In Haaland et al. (1999), the most important determinant for the relative sectoral concentration turns out to be market size, i.e. industries tend to locate close to larger markets. A smaller, but significant effect is also found for labour intensity, i.e. skill-intensive industries seem to concentrate in countries offering highly skilled labour. By use of spatial econometrics ${ }^{5}$, Tirado, Paluzie and Pons (2000) empirically confirm that the industrial intensity (i.e. the share of industrial production in total production) of Spanish provinces strongly increased in the $19^{\text {th }}$ century. It was influenced negatively by the province's share of population, and positively by human capital endowment, relative size of the province's market, and the extent of large scale production (approximated by the province's average tax payment by taxpayer). As the authors compare two points in time before and after the Spanish market integration, they conclude that market integration can be regarded as a trigger of the sharply increased agglomeration of economic activities. Kalemli-Ozcan, Sorensen and Yosha (1999) find higher population density, lower per capita gross domestic product, lower population as well as a higher degree of risk sharing (supposed to represent financial market integration or development) to have a significant increasing impact on the industrial specialisation of regions.

The presented theoretical frameworks point to a number of centripetal forces such as market potential, economies of scale or local demand which seem to be important determinants in the explanation of sectoral concentration tendencies. Transport or transaction costs play an essential role as a centrifugal force according to the theory as well. In case of mobile capital, transaction costs are largely determined by capital market integration and liberalisation. Both, transaction costs and integration variables will capture effects of EU-integration on regional development. The econometric investigations of concentration tendencies in production mostly find some support for the traditional trade theory as well as the new economic geography approaches. Several important exogenous variables are evident. The concentration of industries across space appears to be determined by market size, human capital or labour

\footnotetext{
${ }^{4}$ Amiti (2001) is a first model that explicitly includes capital as a second factor of production in addition to labour. In this approach, however, both production factors are assumed to be immobile across borders. The triggers for agglomeration are increasing returns to scale as well as vertical linkages which can enforce the agglomeration of intermediate input supplier (upstream) firms and manufactures of final goods (downstream firms) in one region. In case of decreasing trade costs, the agglomeration of these vertically linked firms is enforced. In the context of European integration, further extensions introducing mobile capital will, however, be needed.

${ }^{5}$ Spatial econometrics account for spatial interdependencies in the analysis of regions e.g. by use of a regional weight matrix in GLS or ML estimations. For further details see Anselin (1988, 2001).
} 
intensity, scale intensities, and intermediate goods intensities (or market linkages). In addition, integration seems to have an increasing effect on sectoral concentration.

In this study, however, we focus on regional developments and the similarity of sectoral structures of EU regions. Hereby, we investigate the allocation of different industrial sectors within a region and hence, to what extent a country or region is specialised sectorally. By this, we do not explain why a region is especially strong or specialised in a particular sector (what is in the focus of traditional trade theory). Instead, our attention is on the determinants of an uneven allocation of capital within a region, i.e. the level of relative specialisation. As long as regional specialisation arises along with sectoral concentration, its level might equally be influenced by market size or the gravitational force of the centre. In addition, the distance to the centre and integration or liberalisation impacts (extending potential markets and enforcing gravitational forces) seem to be relevant determinants. Finally, a very important aspect to focus on when analysing regional investments is the potential of economic growth within a region, e.g. number of patents and the regional economic situation.

\section{Empirical evidence: What determines the similarity of relative investments in EU regions?}

As a measure of investment specialisation, Gini-coefficients are constructed as in the studies of Krugman (1991), Brülhart (1998), Klüver and Rübel (1998), and Amiti (1999) ${ }^{6}$. In order to abstract from size and classification effects (i.e. the differing importance of sectors and the possibly inadequate disaggregation of economic activity in subsectors), we do not calculate the Gini-coefficient over absolute investment shares, but over relative ones, i.e. investment shares in relation to an economy of reference ${ }^{7}$. This is important as the absolute allocation of production across sectors does not tell anything about a particularly high level of sectoral engagement of that region while this is what we focus on: relative allocation and hence, relative specialisation. It is the unequal size of regions or sectors that generally causes the difference between the absolute and the relative specialisation index ${ }^{8}$. Relative investment

\footnotetext{
${ }^{6}$ However, Sapir (1996) analysing absolute country specialisation with export data made use of the Herfindahl index instead, Greenaway and Hine (1991) of the Grubel-Lloyd, the Michaely as well as the Finger-Kreinin index. Kalemli-Ozcan, Sorensen and Yosha (1999) used a variance-like measure given their focus on risksharing. For a discussion of these measure and their more detailed presentation see Stirboeck (2001).

${ }^{7}$ The Gini-coefficient is well known from the analysis of problems of distribution and is expressed as the ratio of twice the area between the Lorenz curve and the $45^{\circ}$-line. The Lorenz curve is constructed by plotting the - in ascending order - cumulated relative sectoral shares. The Gini-coefficient can be used to focus either on relative or absolute specialisation depending on the precise construction of industrial shares whose distribution is analysed (see below). It gives strong weight to the middle parts of the distribution of relative sectoral shares. As a consequence, changes in industrial sectors similar to the median structure have a larger effect on the value of the Gini-coefficient than changes in industrial sectors at the outer sides of the distribution (Cowell, 1995). However, the coefficient's range between 0 (low concentration) and 1 (high concentration) usually reflects well differences in the level of concentration. Therefore, the Gini-coefficient is the most widely used inequality measure in the analysis of the spatial allocation of sectors or sectoral allocation of regional economic activity. In addition to the calculation of the Gini-coefficient as a measure of relative regional specialisation, we also calculated the Finger-Kreinin-index as well as the coefficient of variation of the relative sectoral shares. The latter stresses changes at the outer sides of the distribution of relative sectoral shares which is in contrast to the weighting of the Gini-coefficient. A graphical comparison of all three indicators shows a similar development over time, the main difference is a generally lower value of the coefficient of variation which, however, does not influence its course. We therefore do not expect sharply differing results when using these alternative measures.

${ }^{8}$ While measures of absolute allocation are influenced by regional size and sectoral classification, measures of relative allocation are influenced by the sectoral patterns of either the economy of reference or the average pattern of the group of countries included. In case of a very special pattern of the reference economy, the relative specialisation pattern of the economic entities analysed can be biased. Further details on the construction of
} 
indices have therefore been constructed measuring the sectoral investment share of the respective region in relation to the average investment share of the sector in the reference economy 9 : $B_{s r}=\left(I_{s r} / \sum_{s} I_{s r}\right) /\left(\sum_{r} I_{s r} / \sum_{r} \sum_{s} I_{s r}\right)$ with I as investment and $\mathrm{s}(\mathrm{r})$ as the sectoral (regional) index. As a result, this adapted „Balassa-index“ reflects the relative investment performance of a region in a sector. If the region's investment in one sector is relatively strong (low) compared to the average sectoral investment of all regions in the reference economy, the index is higher (smaller) than 1.

Measuring the level of relative investment specialisation, the Gini-coefficient is calculated in the following way by first ranking the $\mathrm{B}_{\mathrm{sr}}$ in ascending order:

$$
G_{r}=\frac{\sum_{s=1}^{N}(2 s-1) B_{s r}}{N}-1 .
$$

It thus captures the degree of homogeneity of these relative investment patterns of the respective region ${ }^{10}$. In case of very similar relative investment shares for the different sectors (i.e. similar relations of the regional investment shares for all sectors to their respective average share in the reference economy), we get a Gini-coefficient close to zero representing a low level of relative investment specialisation. This Gini-coefficient ranges between 0 and $(\mathrm{N}-1) / \mathrm{N}$. The standardised Gini-coefficient $\mathrm{G}^{*} \mathrm{~N} /(\mathrm{N}-1)$, referred to as the Lorenz-Münznercoefficient, is used in the estimates.

These relative specialisation indices are calculated with respect to two different perspectives. First, the reference economy for each region is the respective country. Therefore, the allocation of relative investment shares in relation to the average sectoral structure of the respective country is calculated. Second, the EU is chosen to be the reference economy and investment shares are analysed in relation to its sectoral patterns as a whole ${ }^{11}$. Both perspectives lead to slightly different specialisation patterns which are discussed in the following, but both are important. Inside the EU, economic policies and politics are still dominated by nation-states. The focus of national economists and politicians is therefore often restricted to national (economic) developments and potential economic imbalances across the

different relative and absolute concentration and specialisation indices can be found in Stirboeck (2001) as well as Krieger-Boden (1999).

${ }^{9} \mathrm{Up}$ to 17 differentiated sectors - consistent to the industrial classification of Nace Rev. 1 - Nomenclature des activités économiques dans les Communautés Européennes - are available in the REGIO database.

${ }^{10}$ An alternative way of calculating the similarity of relative patterns by use of the Gini-coefficient was applied by e.g. Krugman (1991) and Amiti (1999). According to their measure, the cumulative sums of sectoral shares of the given regions are to be plotted against those of the reference economy ranked according to their relative shares (i.e. the adapted Balassa-indices). Both sectoral structures (and not their relation) are thus directly compared. In case of very equal sectoral structures, we also get a Gini-coefficient near zero. However, both sectoral shares, the one of the respective region as well as the one of the reference economy, influence the value of the Gini-coefficient. If a large sectoral share in e.g. the reference economy is confronted with an even larger sectoral share in the region in focus, the value of the Gini-coefficient is largely determined by this economically important sector. This effect influences the value of the level of relative specialisation for some regions. Regression results for this kind of indicator, however, do only slightly change.

${ }^{11}$ As the data on gross fixed capital formation is not in all cases as complete as we wish it to be, we had to use other data which adequately captures national sectoral shares in the UK and Belgium. In addition, EU sectoral gross fixed capital formation data is not available in the REGIO database either. Therefore, it was referred to data of value added at basic prices in these cases. This is a good proxy for the economic importance of the different sectors, and the same procedure is also adapted by Eurostat when regional or sectoral shares of economic activity are needed. 
regions of one country. In contrast to this stands the overall European perspective which is important when regarding regional developments or imbalances independent of national borders or national investment structures. In addition, EU's financial aid in the framework of regional development programmes ${ }^{12}$ - with the exception of the Cohesion Funds - is accorded only on the basis of regional characteristics, not national patterns.

\section{1 Descriptive features of the specialisation patterns of gross fixed capital formation}

The maximum number of regions included at the NUTS 2-level is 53 (56) for the national perspective (European perspective) while it is 30 (33) at the NUTS 1-level ${ }^{13}$. These regions belong to Belgium, Denmark, France, Luxembourg, Ireland, Italy as well as Great Britain (only NUTS 1). Details are given in the appendix. For all other countries, the sectoral data availability is not sufficient for our kind of analysis. The disaggregation of EU countries into NUTS-regions is primarily based on political or administrative entities. Such "normative" regions are regarded for practical reasons of data availability in the REGIO database but also in accordance with the implementation of regional policies ${ }^{14}$. These regions are not grouped together on the basis of economic criteria. This is often criticised by economists as this might not give us the actual degree of specialisation of economic entities. However, the definition of economic regions might differ for each variable or even sector regarded, i.e. a general specification of regional disaggregation is inappropriate. In addition, the analysis of normative regions disaggregated according to NUTS allows us to focus on the degree of specialisation of a territorial community which is authorised to implement regional policies or is in the focus of regional structural programmes. As the debate about how specialised EU's regions are originates in the question about their regional shock absorbing potential and the necessity of improving regional policies, the analysis of administrative regional entities is one relevant empirical aspect.

Table A4 presents average relative Gini-coefficients for all regions (measuring relative specialisation of capital formation calculated in the national perspective - called GCCF in the following) for the time period 1985 to 1994 as far as data has been available. Table A5 gives the additional perspective of relative specialisation across EU regions with EU being the economy of reference (called GCCFEU). One important feature that can be detected when analysing French, Italian, and Belgian regions (the only countries with available investment data for both NUTS 1- and NUTS 2-levels) is the higher level of specialisation when regarding the more disaggregated NUTS 2-regions in comparison to the NUTS 1-regions. Though this is not surprising as relative sectoral dissimilarities are very likely to be aggregated away in bigger economic entities.

Unsurprising as well, is the fact that the level of relative specialisation in terms of the overall European capital allocation is in general higher than the one in the national context ${ }^{15}$.

\footnotetext{
${ }^{12}$ Objective 1-regions eligible to EU financial assistance in the framework of the Structural Funds are marked by a gross domestic product per capita of less than $75 \%$ of the average EU gross domestic product per capita.

${ }^{13}$ As Ireland, Denmark and Luxembourg are monoregional countries at the NUTS 1- as well as the NUTS 2level, their relative concentration can only be calculated in relation to EU average sectoral shares. Otherwise, the specialisation indices would all be 1 per definition, and the concentration indices thus 0 .

${ }^{14}$ Since the 1961 Brussels Conference on Regional Economies, regional policies are generally applicated in NUTS 2-regions (Eurostat, 1999).

${ }^{15}$ To a minor extent, this difference is also due to the two different ways of calculating average national and EU sectoral shares by gross fixed capital formation shares and value added shares. However, with the exception of
} 
Specialisation is slightly higher in Belgium, and strongly in French and Italian regions - the difference is on average 0.134 in Italian, 0.104 in French, and 0.025 in Belgian regions. This shows that the industrial structure of Belgium (which economically is a very open country) is less differing from the average European structure than the one of France and Italy. However in all countries, the regions' rank with regard to the level of specialisation rarely changes ${ }^{16}$. Some special cases are though obvious. The relative specialisation of the Île de France as well as the one of Centre $(\mathrm{F})$ sharply increases (when measured in relation to average EU shares) what influences their rank. This, of course, is due to the fact that a large share of French production is concentrated in these regions, thereby dominating the sectoral structure of France but not the one of EU.

Further insights into the process of regional specialisation can be gained from a descriptive comparison of the most "extreme" regions ${ }^{17}$. Table A6 and Table A7 focus on the two least and the two most specialised NUTS 2-regions in relation to the national and the average EU sectoral structure. Patterns are very similar for both, the GCCF- and the GCCFEU-variable. With respect to GDP per capita, GFCF in percent of GDP, and net migration ${ }^{18}$, there are no systematic differences between the regions analysed. But those regions with a more uniform relative allocation of investments across industrial sectors are also marked by a higher number of patents, higher absolute GFCF as well as consequently by higher absolute GDP. Higher specialised regions, however, seem to perform worse in economic terms than lower specialised regions with respect to the unemployment rate, the share of regional to total employment, the number of patents, and total regional GDP as well as total regional GFCF. Exceptions though are a number of regions which are - in economic terms - among the most important and which usually are located in the centre of the respective countries ${ }^{19}$. As no causal relationship can be derived from this purely descriptive analysis, econometric analyses are conducted in the following to test for significance and importance of potential determinants.

\section{2 Econometric evidence on the patterns of specialisation of gross fixed capital formation}

As presented above, a number of determinants from different theoretical approaches are supposed to explain the level of regional specialisation of gross fixed capital formation. However, explanatory variables added in this analysis are to some extent limited by the data availability. Including the core variables mentioned above, we test the following specification:

$$
\begin{aligned}
\operatorname{GCCF}(E U)_{i}=\quad & \beta_{0}+\beta_{1} \text { MAR }_{i}+\beta_{2} \text { AREA }_{i}+\beta_{3} \text { PAT }_{i}+\beta_{4} \text { PODEN }_{i}+\beta_{5} U_{E W P_{i}}+\beta_{6} \text { CENTR }_{i} \\
& +\beta_{7} I_{N T_{i}}+\beta_{8} \text { ZENTRREG }_{i}
\end{aligned}
$$

The market size (MAR) of region $\mathrm{i}$ is approximated by gross domestic product (GDP) $)^{20}$. Additional important exogenous variables are the size of a region (AREA), the number of

\footnotetext{
„other services“ and „recovery, repair, trade, lodging, and catering services“, the difference in sectoral shares is of minor extent.

${ }^{16}$ This, however, is rather different for the concentration patterns of UK and Belgian regions with respect to the average EU and their average national sectoral structure. This might to a large extent be due to the low number of sectors that we could include in the analysis of the British and Belgian regions.

${ }^{17}$ A detailed description of these characteristics can be found in Stirboeck (2001) for the national perspective.

${ }^{18}$ Here, only data since 1997 is available.

${ }^{19}$ This effect becomes even more obvious when regarding Bruxelles and the Île de France at the NUTS 1-level.

${ }^{20}$ Further variables reflecting market size are the regional level of gross fixed capital formation, value added at factor costs, total population, total employment as well as (aggregated) compensation of employees.
} 
patents (PAT), population density (PODEN), unemployment rate in percent of working population (UEWP) which are all taken from the REGIO database. The distance of the region to the economic centre (CENTR) capturing effects of peripheral location ${ }^{21}$, variables representing European integration (INT), i.e. economic openness and capital account liberalisation indices, as well as an indicator variable for central, economically most important regions (ZENTRREG) are added. Details on all these variables are given in the data appendix. Unfortunately, data on patent applications has not been available for Corse and Northern Ireland. As a consequence, these two regions are dropped in the estimations when using patents as explanatory variables. In addition, data on patents are only available since 1989. Separate estimations for the shorter time period are therefore presented when patents turn out to be an important variable in panel estimates.

The inclusion of the presented potential explanatory variables in the final estimation models of the cross-sectional analysis has been determined by the result of a likelihood ratio (LR) test at the $10 \%$-level of significance ${ }^{22}$. The decision between two different (non-nested) models for the same period has been made in accordance with the Akaike information criterion (AIC). We estimated variance-corrected standard errors by generalised least squares (GLS) to prevent that potential heteroscedasticity influences the coefficients' significance.

However, we cannot exclude from pure theory a potential problem of reverse causation between the level of investment specialisation and regional gross domestic product or the regional rate of unemployment. In order to control for potential endogeneity problems, instrumental variable regressions have been conducted additionally for both GCCF and GCCFEU. Following one common approach in econometric analysis, lagged values of the unemployment rate as well as of gross domestic product are included as instruments. As a consequence, results are very similar, and most coefficients are even nearly identical ${ }^{23}$.

\section{2.1 Cross-sectional analyses}

Cross-sectional analyses are conducted at the NUTS 2- as well as the more aggregated NUTS 1-level for both the national (GCCF) as well as the EU perspective (GCCFEU) of relative specialisation. Results for the NUTS 2-level are displayed in Table 1a and Table 1b. The best

Unsurprisingly, these all turn out to be highly correlated with gross domestic product (see Table A8a and Table $\mathrm{A} 8 \mathrm{~b}$ in the appendix). Due to this fact, only one of these variables can be included in the explanation of the strength of specialisation of gross fixed capital formation. Preference has hereby been accorded to the GDP variable (which is a good proxy for market size). In most cases, the substitution of GDP by any of the other variables does change the results only negligibly, i.e. the estimated coefficients and models are very robust. In some cases, the use of another variable instead of GDP, e.g. population, would have improved the overall goodness of the estimation. However, GDP was used in the estimations what did not lead to differing results.

${ }^{21}$ In the analysis of sectoral agglomeration or concentration, distances are usually supposed to capture trade costs. Up to a certain level, decreasing transport costs might strengthen agglomeration tendencies. But once reaching this level, theory tells that dispersion factors (such as factor costs in the periphery) can be stronger. The variable's sign is thus not expected ex ante by theory. However, as we focus on regional aspects in this analysis, the simplest and most consistent interpretation of the variable "distance to the economic centre" is that it captures the effect of being far away from the economically most important regions, i.e. the impacts of the peripheral location of a given region.

${ }^{22}$ However, most coefficients as well as the LR tests on the inclusion of further variables are significant at the $5 \%$ - or even the $1 \%$-level of significance.

${ }^{23}$ As data is only available for 1985 to 1994 , instrumental variable cross-section analyses for 1985 had to be omitted. For the same reason, only 30 out of 53 (56) observations can be included in the regressions for 1986 so that the IV estimates cannot capture the same effects as the simple GLS regression. However, for all other years, the same effects can be demonstrated as in the GLS estimates. 
models identified which are displayed in both tables differ a bit. In many cases, identical models for both, GCCF and GCCFEU are significant as well, however, the best estimates have been chosen according to the criteria given above. Coefficients rarely change in their size and never in their sign. The higher gross domestic product and the bigger the size of the region, the more similar relative sectoral shares of gross fixed capital formation turn out to be. In contrast, an increase in the unemployment rate as well as the fact of being a central (economically important) region increase the level of investment specialisation. In some years, population density seems to capture the effect usually picked up by the indicator variable for the central region. Both variables therefore appear to reflect a form of centrality effect. In some years, the number of patents shows a significant increasing effect on the level of specialisation as well.

Table 1a: Cross-sectional analysis: Determinants of GCCF, NUTS 2-regions

\begin{tabular}{|c|c|c|c|c|c|c|c|c|c|c|}
\hline year & 1985 & 1986 & 1987 & 1988 & 1989 & 1990 & 1991 & 1992 & 1993 & 1994 \\
\hline \multirow[t]{2}{*}{ constant } & 5.6389 & 0.5047 & 0.3978 & 0.9713 & 1.2534 & 0.4828 & -2.0743 & -1.9057 & 0.4314 & 0.4053 \\
\hline & 6.8 & 18.24 & 7.48 & 3.23 & 4.6 & 18.68 & -4.65 & -3.97 & 10.98 & 9.91 \\
\hline \multirow[t]{2}{*}{ gdp } & -0.0023 & -0.0018 & -0.0016 & -0.0010 & -0.0010 & -0.0011 & -0.0024 & -0.0032 & -0.0075 & -0.0072 \\
\hline & -3.54 & -2.95 & -2.94 & -2.00 & -2.53 & -2.78 & -4.23 & -4.61 & -6.88 & -6.57 \\
\hline \multirow[t]{2}{*}{ zentrreg } & 0.2533 & 0.1742 & 0.1748 & 0.0946 & 0.1498 & 0.1391 & 0.1882 & 0.2614 & 0.3507 & 0.3758 \\
\hline & 4.38 & 2.13 & 2.3 & 1.26 & 2.24 & 1.83 & 3.28 & 3.96 & 5.46 & 5.84 \\
\hline \multirow[t]{2}{*}{ uewp } & & & 0.0090 & 0.0068 & 0.0054 & & 0.0051 & & 0.0084 & 0.0088 \\
\hline & & & 2.11 & 2.01 & 1.74 & & 1.71 & & 2.25 & 2.56 \\
\hline \multirow[t]{2}{*}{ area } & & -0.0061 & -0.0054 & -0.0042 & -0.0035 & -0.0052 & & & & \\
\hline & & -4.18 & -4.04 & -3.03 & -2.82 & -3.85 & & & & \\
\hline \multirow[t]{2}{*}{ quinn_openn } & -0.5119 & & & -0.0536 & -0.0789 & & 0.1817 & 0.1757 & & \\
\hline & -6.21 & & & -1.89 & -3.03 & & 5.59 & 4.94 & & \\
\hline \multirow[t]{2}{*}{ centr } & 0.2392 & & & & & & & & & \\
\hline & 3.18 & & & & & & & & & \\
\hline \multirow[t]{2}{*}{ pat } & & & & & & & 0.0002 & 0.0002 & 0.0012 & 0.0012 \\
\hline & & & & & & & 2.51 & 2.64 & 4.99 & 4.83 \\
\hline & & & & & & & & & & \\
\hline no. obs. & 30 & 53 & 53 & 53 & 53 & 53 & 52 & 52 & 31 & 30 \\
\hline Prob Chi ${ }^{2}$ & 0.0000 & 0.0000 & 0.0000 & 0.0000 & 0.0000 & 0.0000 & 0.0000 & 0.0000 & 0.0000 & 0.0000 \\
\hline
\end{tabular}

Note: Z-values of GLS-estimates are given in the line below the coefficients. The probability of the Chi ${ }^{2}$-test gives the overall fit of the model. For abbreviations see Table A2 and A3 in the appendix.

Only the interpretation of the empirical influence of the liberalisation indicator taken from Quinn $(1997,2000)^{24}$ is ambiguous as it shows first negative and, since 1990, positive signs. Since these liberalisation indicators are not available at the regional level, but only at the country level, they might pick up country-specific effects in cross-sectional analyses. Controlling for this potential effect, country-specific dummies are added to the presented estimations. These country dummies are relative to Italy as the Italian data is available for all sectors and years. As a result, the liberalisation indicators indeed loose their significance in most cases $^{25}$ or are even dropped due to problems of high collinearity with the country dummies. However, only for few of the yearly regressions (1986, 1990, 1993, and 1994 for GCCF as well as 1990 for GCCFEU), the equation including country-specific indicators is statistically better according to the AIC and the likelihood ratio test result ${ }^{26}$. In addition, the country-specific dummies are - except for the Belgian dummy - rarely significant. This

\footnotetext{
${ }^{24}$ This indicator differentiates between varying levels of liberalisation over time. Its construction is explained in the appendix.

${ }^{25}$ Exceptions are only 1988 and 1989 for GCCF. Here, the Belgian country dummy is dropped in the estimates instead.

${ }^{26}$ Results for the regressions including country dummies are available from the author upon request.
} 
indicates that on the one hand the effects captured by Quinn's liberalisation indicator cannot be picked up equally by country-specific dummies for the different years. On the other hand, we cannot exclude that in these cross-section regressions the liberalisation indicator does not actually measure additional effects or even other impacts. More reliable results will be gained in the pooled regressions as the indicators' variation over time is exploited.

Table 1b: Cross-sectional analysis: Determinants of GCCFEU, NUTS 2-regions

\begin{tabular}{|c|c|c|c|c|c|c|c|c|c|c|}
\hline year & 1985 & 1986 & 1987 & 1988 & 1989 & 1990 & 1991 & 1992 & 1993 & 1994 \\
\hline \multirow{2}{*}{ constant } & 2.2736 & 0.4643 & 0.4230 & 0.4238 & 0.4563 & \begin{tabular}{|l|}
-0.0480 \\
\end{tabular} & -1.2992 & -0.9289 & |0.4454 & 0.4353 \\
\hline & 3.06 & 10.34 & 10.29 & 11.95 & 15.58 & -0.32 & -3.27 & -1.73 & 13.9 & 11.23 \\
\hline \multirow[t]{2}{*}{ gdp } & -0.0025 & -0.0009 & -0.0008 & -0.0007 & -0.0009 & \begin{tabular}{|l|}
-0.0009 \\
\end{tabular} & -0.0008 & -0.0007 & -0.0014 & -0.0011 \\
\hline & -4.44 & -2.04 & -2.02 & -1.8 & -2.81 & -2.89 & -2.91 & -2.31 & -3.78 & -2.76 \\
\hline \multirow[t]{2}{*}{ zentrreg } & 0.1891 & 0.1031 & 0.1210 & 0.0841 & 0.1281 & 0.1097 & 0.1861 & & & \\
\hline & 3.7 & 2.22 & 2.8 & 1.97 & 3.23 & 2.58 & 3.6 & & & \\
\hline \multirow[t]{2}{*}{ uewp } & 0.0078 & 0.0085 & 0.0111 & 0.0093 & 0.0065 & 0.0057 & 0.0078 & 0.0105 & 0.0086 & 0.0081 \\
\hline & 2.21 & 2.26 & 3.23 & 3.28 & 2.46 & 1.97 & 2.96 & 2.71 & 3.23 & 2.82 \\
\hline \multirow[t]{2}{*}{ poden } & & & & & & & & 0.0489 & 0.0487 & 0.0517 \\
\hline & & & & & & & & 2.73 & 3.65 & 3.35 \\
\hline \multirow[t]{2}{*}{ area } & & -0.0039 & -0.0039 & $\mid-0.0031$ & \begin{tabular}{|c|}
-0.0025 \\
\end{tabular} & & & & & \\
\hline & & -3.92 & -4.2 & -3.38 & -2.91 & & & & & \\
\hline \multirow[t]{2}{*}{ quinn_openn } & -0.1798 & & & & & 0.0375 & 0.1269 & 0.0989 & & \\
\hline & \begin{tabular}{l|l|}
-2.46 \\
\end{tabular} & & & & & 3.41 & 4.39 & 2.54 & & \\
\hline \multirow[t]{3}{*}{ centr } & 0.1550 & & & & & & & & & \\
\hline & 2.35 & & & & & & & & & \\
\hline & & & & & & & & & & \\
\hline no. obs. & 30 & 56 & 56 & 56 & 56 & 56 & 53 & 56 & 34 & 34 \\
\hline Prob Chi & 0.0000 & 0.0000 & 0.0000 & 0.0000 & 0.0000 & 0.0000 & 0.0000 & 0.0000 & 0.0000 & 0.0000 \\
\hline
\end{tabular}

Note: see Table 1a.

Besides these inconclusive impacts of the liberalisation indicator, we find plausible and consistent signs for all other coefficients for which significant results are demonstrable. In addition, these coefficients are very robust with respect to the estimation method (i.e. OLS, GLS, IV estimates) as well as to changes in the estimated model or the substitution of gross domestic product by one of the other variables proxying market size such as population. Only for the years 1993 and 1994, the econometric results are not as reliable as in the other years. This is due to the lower number of regions with available data - e.g. for all French regions data is missing.

Changing our focus from NUTS 2- to the more aggregated NUTS 1-level, results - displayed in Table $2 \mathrm{a}$ and Table $2 \mathrm{~b}$ - are very similar ${ }^{27}$. Gross domestic product and the unemployment rate prove to have a significant impact on the level of GCCF in almost all years and on GCCFEU in many years. Central or core regions still show a higher level of relative investment specialisation at NUTS 2-level while population density now demonstrates a joint increasing effect on specialisation in many years. However, if both variables are jointly significant, the size of both coefficients is consistently lower. Only the size of the region does not show a significant and consistent influence at this aggregation level. As NUTS 1-regions are higher aggregated and usually consist of a number of NUTS 2-regions, their size differs much less. In addition, bigger regions are naturally more diversified, so this result is not surprising.

\footnotetext{
${ }^{27}$ Again, instrumental variables estimations have been conducted by use of the lagged unemployment rate and the lagged gross domestic product variable as instruments. Like for the NUTS 2-level, results have been very similar to the simple GLS regressions at the NUTS 1-level.
} 
Table 2a: Cross-sectional analysis: Determinants of GCCF, NUTS 1-regions

\begin{tabular}{|c|c|c|c|c|c|c|c|c|c|c|}
\hline year & 1985 & 1986 & 1987 & 1988 & 1989 & 1990 & 1991 & 1992 & 1993 & 1994 \\
\hline \multirow[t]{2}{*}{ constant } & 0.1943 & 0.1230 & 0.1750 & 0.1920 & 0.2298 & 0.3111 & 0.2810 & 0.2315 & 0.3261 & 0.2939 \\
\hline & 2.1 & 1.79 & 2.87 & 3.58 & 4.66 & 9.43 & 4.85 & 3.98 & 4.19 & 6.76 \\
\hline \multirow[t]{2}{*}{ gdp } & -0.0016 & -0.0007 & -0.0009 & -0.0009 & -0.0010 & -0.0008 & -0.0011 & -0.0010 & & \\
\hline & -1.96 & \begin{tabular}{|l|}
-1.72 \\
\end{tabular} & -2.3 & -2.32 & -2.89 & -2.32 & -3.37 & -3.23 & & \\
\hline \multirow[t]{2}{*}{ zentrreg } & & 0.1305 & 0.1539 & 0.1963 & 0.2505 & 0.1419 & 0.2683 & 0.1637 & & \\
\hline & & 2.19 & 2.38 & 4.06 & 4.91 & 1.77 & 4.76 & 2.39 & & \\
\hline \multirow[t]{2}{*}{ uewp } & 0.0136 & 0.0155 & 0.0126 & 0.0108 & 0.0087 & & 0.0071 & 0.0106 & 0.0095 & \\
\hline & 2.43 & 3.46 & 3.18 & 3.11 & 2.58 & & 1.63 & 2.45 & 2.17 & \\
\hline \multirow[t]{2}{*}{ poden } & 0.0701 & 0.0413 & 0.0383 & & & 0.0339 & & 0.0618 & 0.0693 & 0.0923 \\
\hline & 5.79 & 2.57 & 2.19 & & & 1.54 & & 3.26 & 4.38 & 5.5 \\
\hline \multirow[t]{2}{*}{ centr } & & & & & & & & & & -0.0600 \\
\hline & & & & & & & & & & -0.68 \\
\hline \multirow[t]{2}{*}{ pop } & & & & & & & & & -0.0331 & \\
\hline & & & & & & & & & -3.37 & \\
\hline & & & & & & & & & & \\
\hline no. obs. & 22 & 30 & 30 & 30 & 30 & 30 & 30 & 30 & 22 & 14 \\
\hline Prob Chi & 0.0000 & 0.0000 & 0.0000 & 0.0001 & 0.0001 & 0.0018 & 0.0002 & 0.0000 & 0.0000 & 0.0006 \\
\hline
\end{tabular}

Note: see Table 1a.

Table 2b: Cross-sectional analysis: Determinants of GCCFEU, NUTS 1-regions

\begin{tabular}{|c|c|c|c|c|c|c|c|c|c|c|}
\hline year & 1985 & 1986 & 1987 & 1988 & 1989 & 1990 & 1991 & 1992 & 1993 & 1994 \\
\hline \multirow[t]{2}{*}{ constant } & 1.2197 & 0.2591 & 0.3824 & 0.4627 & 0.4411 & 0.4402 & 0.4031 & 0.2310 & 0.4548 & 0.2947 \\
\hline & 4.55 & 5.99 & 12.67 & 17.99 & 20.33 & 21.86 & 10.38 & 6.43 & 12.34 & 6.36 \\
\hline \multirow[t]{2}{*}{ gdp } & -0.0030 & & -0.0009 & -0.0008 & -0.0007 & -0.0006 & -0.0008 & & -0.0012 & \\
\hline & -5.38 & & -2.97 & -2.52 & -2.75 & -2.85 & $\mid-3.36$ & & \begin{tabular}{|c|}
-2.83 \\
\end{tabular} & \\
\hline \multirow[t]{2}{*}{ zentrreg } & 0.2154 & \begin{tabular}{|l|l|l|}
0.0784 \\
\end{tabular} & 0.1297 & 0.0678 & 0.0788 & 0.1290 & 0.2184 & 0.0904 & & \\
\hline & 4.24 & 2.05 & 3.22 & 1.84 & 2.36 & 4.42 & 5.78 & 2.61 & & \\
\hline \multirow[t]{2}{*}{ uewp } & & \begin{tabular}{|l|l|l|}
0.0119 \\
\end{tabular} & & & & & 0.0050 & 0.0163 & & 0.0073 \\
\hline & & 3.34 & & & & & 1.7 & 4.82 & & 2.73 \\
\hline \multirow[t]{2}{*}{ poden } & & 0.0310 & 0.0361 & & 0.0345 & & & 0.0589 & 0.0625 & 0.0757 \\
\hline & & 2.15 & 2.82 & & 2.7 & & & 4.38 & 4.34 & 7.53 \\
\hline \multirow[t]{2}{*}{ area } & & & & & & & & & 0.0019 & 0.0026 \\
\hline & & & & & & & & & 2.07 & 3.19 \\
\hline \multirow[t]{2}{*}{ quinn_openn } & -0.0694 & & & & & & & & & \\
\hline & -2.87 & & & & & & & & & \\
\hline \multirow[t]{2}{*}{ pat } & & & & & & & & & & -0.0002 \\
\hline & & & & & & & & & & -2.43 \\
\hline \multirow[t]{2}{*}{ centr } & 0.1722 & & 0.1400 & & & & & & & \\
\hline & 3.11 & & 2.6 & & & & & & & \\
\hline & & & & & & & & & & \\
\hline no. obs. & 22 & 33 & 33 & 33 & 33 & 33 & 30 & 33 & 25 & 17 \\
\hline Prob Chi ${ }^{2}$ & 0.0000 & 0.0000 & 0.0000 & 0.0124 & 0.0000 & 0.0000 & 0.0000 & 0.0000 & 0.0000 & 0.0000 \\
\hline
\end{tabular}

Note: see Table 1a.

Only in few years, the estimations significantly improve according to the AIC and the LR test results when adding country-specific variables (1988 and 1991 for GCCF; 1986 and 1992 for GCCFEU). Solely the Belgian country dummy is significant in few cases (1989 and 1991) with respect to the estimates for GCCF. Analysing GCCFEU, Ireland, Denmark, and Luxembourg prove to have significant country dummies in some years as well. However, their significance is rather inconsistent over time. The inclusion of country dummies therefore does not really improve estimates at NUTS 1-level. Analogously, the Quinn liberalisation 
indicator is also not significant any more - besides of the year 1985 for GCCFEU. This might be the result of the decreased number of regions included at NUTS 1-level and therefore even lower variation of the openness indicator. When adding country-specific dummies, the Quinnindicator of openness of 1985 still remains significant while the country dummies do not improve the estimation.

\section{2.2 Pooled estimates and panel data analyses}

In the following, a number of results for pooled data and panel estimations are presented. Pooled data estimates, given in Table $3 a$ and $3 b$, display results very similar to those of the cross-section analyses. Since regressions including patents as explanatory variables only start in 1989 (due to the data availability), two regression models are displayed for the two different time periods when relevant. However, all regressions are robust as the coefficients for the other exogenous variables do hardly change. Again, higher gross domestic product and a bigger size of a region diminish the level of specialisation of this region while a higher unemployment rate, population density ${ }^{28}$ and the fact of being a central region increase its level. The influence of the distance to this central region on the level of specialisation is positive as well. The more peripheral a region is, the less similar is its sectoral structure to the average structure of its country as well as of the EU.

This time, the inclusion of country-specific effects, again relative to Italy, generally improves the estimates according to the AIC and likelihood ratio tests. However, only Belgian regions turn out to have a significantly higher level of GCCF compared to Italian regions. In the regressions for GCCFEU - which in addition to Belgian, Italian, French and British regions also include Ireland, Denmark, and Luxembourg as a NUTS 1- or NUTS 2-region - all country-specific indicator variables are generally significant. Besides the Belgian regions, which are again marked by a significantly higher level of specialisation than the Italian regions, all other regions have a significantly lower level of specialisation. But we cannot be sure that the significant positive fixed country effect for Belgium is due to country-specific characteristics. However, this dummy might also capture the poor quality of the Belgian data. In contrast to fixed country effects, fixed time effects estimated relative to 1994 never improve the estimates (see Table A10).

We are now, finally, aware of a consistent positive impact of liberalisation on the level of specialisation. The Quinn openness indicator is not only significant in most of the pooled regressions, it also remains significant in the improved estimates including country-specific dummies. Its significance is even stronger in the estimations for GCCFEU which include a higher number of countries. Again, we get no differing results for both, GCCF and GCCFEU, when conducting instrumental-variable regressions to exclude potential problems of endogeneity (see Table A11) ${ }^{29}$.

\footnotetext{
${ }^{28}$ The coefficient for population density, however, changes its sign in the estimates for GCCFEU at NUTS 2level when including country-specific dummies. Running separate estimates for either population density or the central region dummy, we get positive signs again.

${ }^{29}$ In this table, we display the results for the first lag of GDP and UEWP used as instruments. We also tested for robustness by using GDP and UEWP lagged two periods. However, the results did hardly change.
} 
Table 3a: Panel estimates, pooled regressions: Determinants of GCCF

\begin{tabular}{|l|r|r|r|r|r|r|r|r|}
\hline & NUTS 2 & NUTS 2 & NUTS 2 & NUTS 2 & NUTS 1 & NUTS 1 & NUTS 1 & NUTS 1 \\
\hline & $1985-94$ & $1985-94$ & $1989-94$ & $1989-94$ & $1985-94$ & $1985-94$ & $1989-94$ & $1989-94$ \\
\hline constant & 0.3794 & 0.2317 & 0.3084 & 0.2329 & 0.0703 & 0.0391 & -0.0422 & 0.1071 \\
\hline & 8.87 & 5.61 & 4.42 & 3.43 & 1.47 & 0.85 & -0.62 & 1.49 \\
\hline gdp & -0.0012 & -0.0010 & -0.0023 & -0.0018 & -0.0008 & -0.0009 & -0.0016 & -0.0018 \\
\hline & -7.41 & -7.3 & -6.49 & -4.94 & -5.78 & -6.3 & -5.53 & -6.46 \\
\hline zentrreg & 0.1024 & 0.1799 & 0.0835 & 0.1700 & 0.1530 & 0.1987 & 0.1334 & 0.1663 \\
\hline & 3.13 & 5.89 & 2.07 & 4.52 & 6.18 & 8.37 & 4.68 & 6.33 \\
\hline uewp & 0.0045 & 0.0055 & 0.0039 & 0.0048 & 0.0089 & 0.0084 & 0.0061 & 0.0059 \\
\hline & 3.72 & 5.01 & 2.76 & 3.76 & 6.76 & 6.82 & 4.18 & 4.41 \\
\hline poden & 0.0279 & 0.0033 & 0.0394 & 0.0136 & 0.0510 & 0.0269 & 0.0576 & 0.0374 \\
\hline & 3.58 & 0.45 & 4.16 & 1.5 & 8.62 & 4.2 & 8.41 & 5.33 \\
\hline area & -0.0056 & -0.0040 & -0.0044 & -0.0029 & -0.0002 & -0.0002 & 0.0004 & 0.0006 \\
\hline & -10.94 & -6.88 & -6.44 & -3.59 & -1.02 & -0.87 & 1.64 & 2.41 \\
\hline quinn_openn & 0.0045 & 0.0069 & 0.0105 & 0.0072 & 0.0100 & 0.0107 & 0.0223 & 0.0105 \\
\hline & 1.39 & 2.33 & 2.03 & 1.47 & 2.70 & 3.06 & 4.13 & 2.00 \\
\hline pat & & & 0.0002 & 0.0001 & & & 0.0001 & 0.0001 \\
\hline & & & 4.01 & 2.65 & & & 3.71 & 4.19 \\
\hline centr & 0.0118 & 0.1178 & -0.0094 & 0.1108 & 0.0754 & 0.1348 & 0.0458 & 0.0847 \\
\hline & 0.59 & 5.73 & -0.32 & 3.51 & 3.45 & 6.11 & 1.73 & 3.3 \\
\hline dum_fra & & 0.0272 & & 0.0103 & & 0.0120 & & -0.0381 \\
\hline & & 2.35 & & 0.55 & & 0.81 & & -1.86 \\
\hline dum_bel & & 0.1613 & & 0.1569 & & 0.1290 & & 0.0998 \\
\hline & & 10.44 & & 7.93 & & 6.77 & & 4.7 \\
\hline dum_ukd & & -- & & -- & & -0.0005 & & -0.0395 \\
\hline & & & & & & -0.05 & & -2.68 \\
\hline & & & & & & & & \\
\hline no. obs. & 463 & 463 & 267 & 267 & 268 & 268 & 151 & 151 \\
\hline SSR & 4.811 & 3.887 & 2.365 & 1.896 & 1.510 & 1.267 & 0.639 & 0.489 \\
\hline Log Likeli & 400.232 & 449.593 & 252.130 & 281.613 & 313.720 & 337.214 & 198.312 & 218.557 \\
\hline Prob Chi ${ }^{2}$ & 0.0000 & 0.0000 & 0.0000 & 0.0000 & 0.0000 & 0.0000 & 0.0000 & 0.0000 \\
\hline AlC & -1.694 & -1.899 & -1.821 & -2.027 & -2.281 & -2.434 & -2.507 & -2.736 \\
\hline
\end{tabular}

Note: see Table 1a.

In contrast to the cross-section estimates presented above, time correlation effects might be of importance in panel data. This means that autocorrelation of the residuals cannot be excluded a priori. In order to take account of these potential effects, the lagged endogenous variable is included in the estimates to capture possible first-order serial correlation effects. The use of other, more sophisticated specifications of dynamic adjustments is possible ${ }^{30}$. However, the methodological discussion about the optimal dynamic specification in the econometric analysis of panel data is still ongoing. We therefore only include the endogenous variable lagged one period when checking the robustness of the above presented results. Table A11 shows the estimates of this specification for the NUTS 2-regions. In the estimates with country fixed effects, almost all coefficients remain significant and their sign unchanged ${ }^{31}-$ only the population density variable generally looses its explanatory power. However, the empirical impact of the variables identified so far is mostly confirmed.

\footnotetext{
${ }^{30}$ See Baltagi (1995) for an account of this issue.

${ }^{31}$ The size of the exogenous variables' coefficients naturally changes due to the dynamic relation specification of the relationship.
} 
Table 3b: Panel estimates, pooled regressions: Determinants of GCCFEU

\begin{tabular}{|c|c|c|c|c|c|c|}
\hline & NUTS 2 & NUTS 2 & NUTS 2 & NUTS 2 & NUTS 1 & NUTS 1 \\
\hline & 1985-94 & 1985-94 & 1989-94 & 1989-94 & 1985-94 & 1985-94 \\
\hline \multirow[t]{2}{*}{ constant } & 0.3453 & 0.3112 & 0.2734 & 0.3687 & 0.2593 & 0.2778 \\
\hline & 9.57 & 8.6 & 4.5 & 6.25 & 6.35 & 6.75 \\
\hline \multirow[t]{2}{*}{ gdp } & -0.0009 & -0.0010 & -0.0015 & -0.0020 & -0.0004 & -0.0005 \\
\hline & -7.14 & -7.38 & $\mid-5.01$ & -6.04 & -4.16 & -3.8 \\
\hline \multirow[t]{2}{*}{ zentrreg } & 0.1216 & 0.2342 & 0.0849 & 0.1856 & 0.1013 & 0.1558 \\
\hline & 6.58 & 8.5 & 4.08 & 5.81 & 7.02 & 6.83 \\
\hline \multirow[t]{2}{*}{ uewp } & 0.0087 & 0.0075 & 0.0085 & 0.0075 & 0.0072 & 0.0067 \\
\hline & 8.54 & 7.66 & 6.58 & 6.37 & 6.73 & 5.67 \\
\hline \multirow[t]{2}{*}{ poden } & 0.0136 & -0.0134 & 0.0267 & 0.0017 & 0.0359 & 0.0321 \\
\hline & 2.3 & -2 & 3.58 & 0.21 & 8.06 & 5.23 \\
\hline \multirow[t]{2}{*}{ area } & -0.0032 & -0.0021 & -0.0017 & 0.0002 & -0.0003 & 0.0002 \\
\hline & -8.76 & -3.94 & -3.66 & 0.29 & -1.85 & 1.06 \\
\hline \multirow[t]{2}{*}{ quinn_openn } & 0.0072 & 0.0068 & 0.0130 & 0.0058 & 0.0063 & 0.0062 \\
\hline & 2.6 & 2.63 & 2.88 & 1.36 & 1.97 & 2 \\
\hline \multirow[t]{2}{*}{ pat } & & & 0.0001 & 0.0002 & & \\
\hline & & & 2.77 & 3.8 & & \\
\hline \multirow[t]{2}{*}{ centr } & 0.0513 & 0.1237 & & & 0.0606 & 0.0356 \\
\hline & 3.00 & 6.66 & & & 3.03 & 1.68 \\
\hline \multirow[t]{2}{*}{ dum_fra } & & -0.0208 & & -0.0681 & & -0.0506 \\
\hline & & -1.99 & & -4.25 & & -3.57 \\
\hline \multirow[t]{2}{*}{ dum_bel } & & 0.0920 & & 0.0539 & & -0.0430 \\
\hline & & 6.6 & & 3.49 & & \begin{tabular}{|c|}
-2.35 \\
\end{tabular} \\
\hline \multirow[t]{2}{*}{ dum_ire } & & -0.0504 & & -0.1136 & & -0.0967 \\
\hline & & -0.97 & & -1.75 & & -2.78 \\
\hline \multirow[t]{2}{*}{ dum_lux } & & -0.1970 & & -0.2613 & & -0.0927 \\
\hline & & -4.82 & & -5.32 & & -2.56 \\
\hline \multirow[t]{2}{*}{ dum_den } & & -0.1249 & & -0.1654 & & -0.1485 \\
\hline & & -3.02 & & -3.31 & & -4.77 \\
\hline \multirow[t]{2}{*}{ dum_ukd } & & -- & & -- & & -0.0011 \\
\hline & & & & & & -0.10 \\
\hline & & & & & & \\
\hline no. obs. & 487 & 487 & 282 & 282 & 292 & 292 \\
\hline SSR & 3.9500 & 3.3305 & 2.1533 & 1.6841 & 1.4399 & 1.2745 \\
\hline Log Likeli & 481.32 & 522.86 & 287.22 & 321.87 & 361.25 & 379.06 \\
\hline Prob Chi ${ }^{2}$ & 0.0000 & 0.0000 & 0.0000 & 0.0000 & 0.0000 & 0.0000 \\
\hline AIC & -1.944 & -2.094 & -1.98 & -2.191 & -2.42 & -2.5 \\
\hline
\end{tabular}

Note: see Table 1 a.

Throughout all regressions, the predicted values were in the range between 0 and 1 , so that our restricted endogenous variable did not impose an econometric modelling problem. The use of a logistic transformation of the regression specification - limiting the range of y to lie in the interval 0,1 - is a more sophisticated procedure, but does not change our results as none of the predicted values lies at the outer sides of the given range. The results for additional pooled regressions in logit terms are presented in the appendix Table A12.

In order to further exploit the time and cross-sectional structure of the data and to check for robustness of our results, fixed effects (within) estimates and between estimates are conducted additionally $^{32}$. Fixed effects estimates control for region-specific differences by adding a

\footnotetext{
${ }^{32}$ First-difference estimates - explaining the change in the level of specialisation - are not convincing neither at the NUTS 2- nor at the NUTS 1-level. This might largely be due to the fact that many of the explanatory
} 
specific constant for each region 33 . Within estimates ("WE") explain the deviation of the regional observations from their respective group (regional) means, thereby excluding all region-specific determinants from these fixed effects estimates. Within estimates thus provide us with further insights on the variation within the groups (in our case within the regions). Between effects ("BE"), in contrast, explain the variation between the different groups only focusing on the groups' means and on region-specific characteristics ${ }^{34}$.

By means of fixed effects within estimates, only few significant impacts can be detected. For the panel of all NUTS 2- (NUTS 1-)regions, only population density consistently proves to be a relevant exogenous variable in explaining the variation of the level of regional specialisation over time. Since the variation of population density over time within a region is of minor extent, this effect is not really convincing. All in all, the within-estimates do not contribute to the explanation of regional specialisation patterns within the groups.

Table 4: Panel estimations: Determinants of investment specialisation

\begin{tabular}{|l|r|r|l|l|l|l|l|r|}
\hline & Nuts 2 & Nuts 2 & Nuts 1 & Nuts 1 & Nuts 2 & Nuts 2 & Nuts 1 & Nuts 1 \\
\hline & gccf & gccfeu & gccf & gccfeu & gccf & gccfeu & gccf & gccfeu \\
\hline & WE & \multicolumn{1}{l}{ WE } & WE & WE & BE & BE & BE & BE \\
\hline constant & 0.7309 & 0.6376 & 0.5227 & 0.6551 & 0.4705 & 0.4289 & 0.1804 & 0.3203 \\
\hline & 4.59 & 8.64 & 6.09 & 7.20 & 19.04 & 13.1 & 3.14 & 8.43 \\
\hline gdp & & & & 0.0004 & -0.0010 & -0.0008 & -0.0007 & -0.0004 \\
\hline zentrreg & & & & 1.800 & -2.86 & -2.46 & -2.06 & -1.72 \\
\hline & & & & & & 0.0108 & 0.1308 & 0.0842 \\
\hline uewp & & & 0.0063 & & & & 0.0117 & 0.0095 \\
\hline & & & 3.8 & & & & 3.03 & 3.52 \\
\hline poden & -1.2271 & -0.5514 & -0.6952 & -0.6475 & 0.0463 & 0.1200 & 0.0508 & 0.0375 \\
\hline & -2.50 & -2.29 & -3.49 & -2.87 & 2.76 & 3.13 & 2.91 & 3.38 \\
\hline area & & & & & -0.0053 & -0.0033 & & \\
\hline & & & & & -4.42 & -3.95 & & \\
\hline pat & 0.0003 & & & & & & & \\
\hline & 1.83 & & & & & & & \\
\hline & & & & & & & & \\
\hline no. obs. & 267 & 487 & 268 & 292 & 463 & 487 & 268 & 292 \\
\hline no. groups & 52 & 56 & 30 & 33 & 53 & 56 & 30 & 33 \\
\hline$R^{2}$ within & 0.0398 & 0.0121 & 0.093 & 0.0397 & 0.0012 & 0.0000 & 0.0303 & 0.0122 \\
\hline$R^{2}$ between & 0.2218 & 0.1026 & 0.4322 & 0.3518 & 0.5262 & 0.4371 & 0.7210 & 0.6543 \\
\hline$R^{2}$ overall & 0.2050 & 0.0886 & 0.4007 & 0.2924 & 0.4594 & 0.3492 & 0.6481 & 0.5048 \\
\hline Prob F & 0.0132 & 0.0225 & 0.0000 & 0.0055 & 0.0000 & 0.0000 & 0.0000 & 0.0000 \\
\hline
\end{tabular}

Note: T-values are given in the line below the coefficients. For abbreviations, see Table A2 and A3 in the appendix. WE stands for fixed effects (within) estimates and BE for between estimates.

In additional fixed effects estimates with explicit region-specific constants, we find that the region-specific constants are generally significant at the $1 \%$-level and turn out to be the most important determinants in the explanation of the specialisation levels. Only in the estimates for GCCF at NUTS 2-level, two regional constants (being the one for Île de France and the one for Rhône-Alpes) are not significant when including the number of patents as a determinant and thus running the regression only for the shorter time period. The region-

\footnotetext{
variables are simply eliminated by the construction of the first difference. This is the case for the indicator variable for central regions, but also for the only slightly varying variables such as the size of a region, the degree of liberalisation, population density as well as the distance to the economic centre of the respective country.

${ }^{33}$ Using this approach, we have to omit the overall constant.

${ }^{34}$ For further details on panel data analyses, see e.g. Baltagi (1995).
} 
specific constants' levels differ largely in these estimations. The one of Bruxelles-capital is always the highest, usually at a large distance to even the second largest regional constant. In the econometric analysis of GCCFEU we find all regional constants to be significant for the specification at the NUTS 2-level. However, the fixed effects estimates at NUTS 1-level strongly improve when excluding the - hardly varying - population density variable from the specification. And again, we find the fixed regional effects to be the only dominant impact on specialisation in these estimates. Though we have a - sometimes not negligible - variation of the specialisation level of one region over time, this variation can only be explained by the presented estimates to a minor extent. The change in the level of specialisation of one region over time might therefore not underlie systematic changes but rather be the result of random disturbances ${ }^{35}$.

In contrast to the rather low explanatory power of these within estimates are the results of between effects estimates ("BE") which explain the variation of the level of specialisation between regions. The results are very similar to those of the cross-sectional and the pooled regressions presented above. Gross domestic product, regional size, the unemployment rate, population density, the indicator variable for the central region as well as the distance to the economic centre of the respective country are of the same sign and about the same size as in the other regressions.

All explanatory variables are consistently significant in pooled and between estimates and are of strong importance in the explanation of systematic differences in the specialisation levels. The variation over time, though, is not explained by our regressions. It is now evident that regional characteristics determine the respective level of specialisation while the variation within a region over time cannot be found to be of systematic nature.

\section{Economic perspectives and effects of EU integration}

The regression results we find in cross-sectional and pooled regression analyses as well as between effects estimates consistently point to a high importance of market size, regional size, the location in the centre, the distance to the centre, and the population density of a region as well as the unemployment rate and economic and capital market integration in the explanation of relative regional investment specialisation. Our results on the impacts of market size, the population density of a region and of capital market or economic liberalisation on specialisation levels are in line with Kalemli-Ozcan, Sorensen and Yosha (1999) who found lower population, higher population density and higher risk-sharing (as a proxy for capital market integration) to increase regional specialisation of production. In addition, we controlled for the effect of further economic variables, in particular the unemployment rate, the number of patents of a region as well as its distance from the centre.

Market size reflects the economic as well as demand potential of a region. The better it is, the lower relative investment specialisation tends to be. However, this significant impact of market size is in contrast to the increasing impact of market size on sectoral agglomeration empirically found by Haaland et al. (1999) and Tirado, Paluzie and Pons (2000). While according to their results - firms tend to locate close to large markets, our empirical results show that regions with a larger market seem to attract capital of all types of sectors with a more even relative allocation (hence showing a lower level of relative regional specialisation)

\footnotetext{
${ }^{35}$ It is also possible that measurement errors as well as the changing number of available sectors have some influence on the variation of the level of regional concentration over time which then naturally cannot be explained by economic determinants.
} 
than smaller markets. Economic activity in regions with a lower gross domestic product seems to be specialised to a higher degree. However, the determinants of the location of particular sectors across EU regions is not subject of this study.

Table 5: Impact of economic variables on the level of specialisation

\begin{tabular}{|l|c|}
\hline Economic variable & Sign of impact on GCCFEU \\
\hline Gross domestic product & - \\
\hline Fact of being a central region & + \\
\hline Unemployment per working population & + \\
\hline Population density & + \\
\hline Size if a region & - \\
\hline Indicator of openness & + \\
\hline Distance to economic centre & + \\
\hline Patents & + \\
\hline
\end{tabular}

In addition to regions with a larger market size, regions with a bigger size tend to have a more similar relative distribution of investments. But the significance of the regional size variable might simply be due to the fact that bigger regions are logically more diversified in their production structure than smaller regions. The fact that NUTS 1-regions are less varying in their size as well as more evenly diversified than NUTS 2-regions leads to an insignificant size variable at the NUTS 1-level. This demonstrates that it is very important to analyse equally big regions. Thus preference has to be accorded to regions as small as possible to avoid that aggregation cancels out potential specialisation patterns. Controlling for regional size effects in the estimates is therefore essential.

In contrast to the fact that larger markets do not show a strong investment specialisation in only few sectors is the result we find for a number of economically very important regions: Central regions (and equally regions with a high population density) demonstrate a significantly higher level of relative investment specialisation. This increasing effect counteracts the decreasing impact of the large market size. But, the high importance of the centrality indicator variable which captures an outstanding strong fixed effect for Brussels, Lazio, and the Île de France is in line with polarisation theory and new economic geography which predict cumulative causation and self-reinforcing agglomeration. Regions having once gained a particularly high potential of market or factor access attract further firms. Supposedly, sectors with firms underlying positive economies of scale or economies of localisation expand in the core.

In addition, the impact of the distance of a given region to its (economic) centre on the level of specialisation is positive. This means that peripheral regions are more different from the average EU structure than regions closer to the centre. Both, the high specialisation of core as well as of peripheral regions is in line with new economic geography predictions. In contrast to the specialisation of core regions, we expect the specialisation of peripheral regions to occur in sectors with low economies of scale and possibly high labour-intensity. However, the sectoral patterns of regional specialisation remain the subject of further research.

The impact of European integration on specialisation patterns is captured by the influence of market liberalisation and openness. In this context, capital market integration which improves the potential mobility of capital is especially important when regarding dissimilarities in the allocation of relative investments. In addition to the direct measuring of the impacts of economic openness presented above we therefore also tested for the influence of capital market integration in the pooled estimates. This is displayed in Table A12. All explanatory 
coefficients are in general very similar to the coefficients in the models with the openness indicator. The correlation between both indicators is about $0.77(0.68)$ for the regions at NUTS 2-level (NUTS 1-level). The indicator of liberalisation of capital accounts ranges between 0.5 and 4 while the economic openness indicator goes up to 14 when perfect openness is reached. As a consequence the coefficient of the capital account liberalisation indicator is higher than the other coefficient in our estimates. However, we cannot conclude on a difference in the strength of the indicators' influence from this fact.

The results of our regressions clearly demonstrate an increasing impact of liberalisation on investment specialisation, so that the perfect liberalisation and capital market integration within EMU seem to further augment specialisation patterns. Instead of a stronger diversification, European regions might end up with an increasingly different relative investment structure in the process of market integration. If this effect continues, further liberalisation would lead to a higher risk of asymmetric shocks. However, specialisation need not always be negative even though production structures become less diversified. The specialisation in an industrial sector providing a high growth potential might be an asset and improve the regional competitiveness in spite of a highly asymmetric industrial structure.

The unemployment rate reflects negative economic performance of a region (not accounting for migration effects etc.). The worse the economic performance is, the stronger the structural dissimilarity to the average patterns of EU turns out to be in our empirical analyses. The number of patents of a region is significant in many estimations as well, though not in all. Its coefficient is mostly positive, i.e. we have a first indication that a higher number of patents increases relative regional specialisation as well. Possibly patents only attract investments of very particular sectors as they play a strong role in many important, but not in all sectors.

This study is limited with respect to two aspects. First, we deal with regional patterns without taking into account regional interdependencies which are probable when analysing regional effects and especially specialisation tendencies. Further improvements of the estimations could thus be achieved by controlling for spatial autocorrelation effects. The appropriate tool for such an analysis would be the use of spatial econometrics. Second, our analysis focuses on the determinants of regional investment specialisation levels. We find some evidence for the stronger specialisation of regions in the extreme localisations core and periphery. As mentioned above, the further analysis of sectoral patterns of relative specialisation is an important aspect when focusing on regional specialisation to detect possible regional imbalances by e.g. core-periphery patterns of the localisation of capital-intensive or growthoriented sectors.

\section{Bibliography}

AMiтi, M. (1999): Specialization Patterns in Europe, Weltwirtschaftliches Archiv 135 (4), 573-593.

AMiti, M. (2001): Location of Vertically Linked Industries: Agglomeration Versus comparative Advantage, CEPR Diskussion Paper No. 2800.

ANSELIN, L. (1988): Spatial econometrics: methods and models, Dordrecht, Kluwer Academic Publishers.

Anselin, L. (2001): Spatial Econometrics, in: Baltagi, B (Hrsg.): A Companion to Theoretical Econometrics, Oxford, Basil Blackwell, 310-330.

BALTAGI, B.H. (1995): Econometric Analysis of Panel Data, Wiley, Chichester.

BRÜHLHART, M. (1998): Trading Places: Industrial Specialisation in the European Union, Journal of Common Market Studies 36 (3) 1998, 319-346.

Cowell, F. A. (1995): Measuring Inequality, London, Prentice Hall. 
Danthine, J.-P., F. GiavaZZI AND E-L. VON Thaden (2000): European Financial Markets after EMU: A First Assessment, CEPR Diskussion Paper, No. 2413.

DiXIT, A.K. AND J.E. STIGLITZ (1977): Monopolistic Competition and Optimum Product Diversity, American Economic Review, 67, 297-308.

EUROPEAN COMMISSION (1999): Specialisation and (Geographic) Concentration of European Manufacturing - Background Paper for "The Competitiveness of European Industry: 1999 Report”, Enterprise DG, Working Paper $\mathrm{N}^{\circ} 1$.

EUROPEAN COMMISSION (2000): Report from the Commission - Economic Reform: Report on the functioning of Community product and capital markets, $\operatorname{COM}(2000) 881$ final, Brussels.

EuROSTAT (1999): Statistik kurzgefaßt, Allgemeine Statistik 1-3/1999, Luxembourg.

GREENAWAY, D., AND R.C. HINE (1991): Intra-industry Specialization, Trade Expansion and Adjustment in the European Economic Space, Journal of Common Market Studies 29(6), 389-403.

HaAland, J.I. , Kind, H.J., Midelfart-KNARVIK, K.H. AND J. TORSTEnsson (1999): What determines the economic geography of Europe?, Centre for Economic Policy Research, Discussion Paper No. 2027, London.

HIRSCHMAN, A. (1958): The Strategy of Economic Development, Yale University Press, New Haven.

IMF (several years): Annual Report on Exchange Arrangements and Exchange Restrictions, Washington.

KALEMLI-OZCAN S., B.E. SORENSEN AND O. Yosha (1999): Risk Sharing and Industrial Specialization: Regional and International Evidence, mimeo.

KLÜVER, A. AND G. RÜBEL (1998): Räumliche Industriekonzentration und die komparativen Vorteile von Ländern - eine empirische Studie der Europäischen Union, Passauer Diskussionspapiere, Diskussionsbeitrag No. 5-98, Passau.

KRIEGER-BODEN, C. (1999): Nationale und regionale Spezialisierungsmuster im europäischen Integrationsprozeß, Die Weltwirtschaft (2), 234-254.

Krugman, P. (1991): Geography and Trade, Cambridge/Mass., MIT Press.

KRUGMan, P. (1995): Development, Geography and Economic Theory, MIT Press.

Krugman, P. (1996): The Self Organizing Economy, Blackwell Publishers.

Krugman, P. (1998): What's New about the New Economic Geography?, Oxford Review of Economic Policy 14 (2), 1998, 7-17.

KRUGMAN P. AND A.J. VENABLES (1995): Globalization and the Inequality of Nations, Quarterly Journal of Economics 110(4), 857-880.

LINNEMANN, H. (1966): An Econometric Study of International Trade Flows, North-Holland, Amsterdam.

MYRDAL, G. (1957): Economic Theory and Under-Developed Regions, London.

QuINN, D. (1997): The Correlates of Change in International Financial Regulation, American Political Science Review, 91(3), 531-551.

QUINN, D. (2000): Democracy and International Financial Liberalization, mimeo.

SAntillan, J., M. BAYle AND C. Thygesen (2000): The Impact of the Euro on Money and Bond Markets, Occasional Paper No. 1, European Central Bank

SAPIR, A. (1996): The Effects of Europe's Internal Market Program on Production and Trade: A First Assessment, Weltwirtschaftliches Archiv 132 (3), 457-475.

STIRBÖCK, C. (2001): Agglomeration Tendencies in EU Regions: Where Does Capital Go?, ZEW Discussion Paper No.01-28.

TinBERgEN, J. (1962): Shaping the World Economy, Suggestions for an International Economic Policy, Twentieth Century Fund, New York.

TIRADO A., E. PALUZIE AND J. PONS (2000): Economic integration and industrial location: The case of Spain before WWI, paper presented at the EEA-meeting in Bolzano in September 2000.

VENABLES, A.J. (1996): Equilibrium Locations of Vertically Linked Industries, International Economic Review 37, 341-359. 


\section{Appendix}

\section{Data description}

The regional disaggregation of the data is given according to the Nomenclature of Territorial Units for Statistics (NUTS - Nomenclature des unités territoriales statistiques). The REGIO database disaggregates data for the three aggregation levels NUTS 1, 2 and 3. However, data for GFCF is not available further disaggregated than the NUTS 2-level. In addition, it is not complete (with regard to the regional and/or the sectoral disaggregation - the latter needed for the calculation of the specialisation indices). Data availability is sufficient for the seven countries given below. Here, the UK does not provide data disaggregated further than NUTS 1-level. Luxembourg, Denmark as well as Ireland are only regarded as one single region at the NUTS 1- as well as at the NUTS 2-level (=monoregional countries). The maximum number of regions available is therefore 33 at the NUTS 1-level and 56 at the NUTS 2-level.

Table A1: Regional data for GFCF from the REGIO database

\begin{tabular}{|l|l|l|l|l|}
\hline Country & $\begin{array}{l}\text { NUTS } \\
\text { level }\end{array}$ & $\begin{array}{l}\text { Respective national } \\
\text { disaggregation level }\end{array}$ & $\begin{array}{l}\text { Number of } \\
\text { regions } \\
\text { NUTS 1 }\end{array}$ & $\begin{array}{l}\text { Number of } \\
\text { regions } \\
\text { NUTS 2 }\end{array}$ \\
\hline UK & 1 & $\begin{array}{l}\text { Groups of Counties or } \\
\text { local authority regions }\end{array}$ & $\begin{array}{l}11 \\
\text { (with 3 n.a.) }\end{array}$ & n.a. \\
\hline Belgium & 2 & Provinces & 3 & 11 \\
\hline France & 2 & Régions & 8 & 22 \\
\hline Italy & 2 & Regioni & 11 & 20 \\
\hline Denmark & $1 \& 2$ & - & 1 & 1 \\
\hline Ireland & $1 \& 2$ & - & 1 & 1 \\
\hline Luxembourg & $1 \& 2$ & - & 1 & 1 \\
\hline Total number of regions & $33(+3$ n.a.) & 56 \\
\hline
\end{tabular}

Note: Version of NUTS 1995. French oversea departments (DOM - départements outre-mer) are not counted in total sums for France as well as for the EU.

Data is taken from the Eurostat REGIO Database (yearbooks up to 2000) which - for gross fixed capital formation - comprises data for the years 1985 to 1994. All data included in the analysis is based on ESA79.

Table A2: List of explanatory variables, REGIO Database

\begin{tabular}{|l|l|l|}
\hline abbreviation & variable & unit \\
\hline gfcf & Gross Fixed Capital Formation & Currency: Billions of ECU \\
\hline totem & Total Employment & in 1000 persons \\
\hline coe & Compensation of employees & Currency: Billions of ECU \\
\hline vafp & Gross value added at factor costs & Currency: Billions of ECU \\
\hline gdp & Gross domestic product & Currency: Billions of ECU \\
\hline pat & European R\&D patent applications & total number \\
\hline uewp & Total Unemployment rates & in \% OF WORKING POPULATION \\
\hline pop & Total annual average population & in Mio. PERSONS \\
\hline poden & Population density & in 1000 INHABITANTS/KM2 \\
\hline
\end{tabular}

In addition to the available national account data, a number of further variables has been used in the econometric analysis. The distance to the centre (centr) captures peripheral effects. It is measured by the optimal route distance between the regional capital and the centre of the respective country. Centres are Paris, Rome, London and Brussels. The distance is defined to be 1 for Denmark, Luxembourg as well as Ireland, and it is equally 1 for the regions 
containing the capital of the respective country. Central and economically important regions (zentrreg) in the analysis are Île de France (France), Brussels (Belgium), and Lazio (Italy).

Table A3: List of further explanatory variables

\begin{tabular}{|l|l|l|}
\hline abbreviation & variable & unit \\
\hline centr & distance to centre, proxy for transport costs & metres \\
\hline zentrreg & regional dummy set for central region & 0 or 1 \\
\hline quinn_openn & indicator of openness per country & $0-14$ (variation by 0.5) \\
\hline quinn_ca & indicator of capital account liberalisation per country & $0-4$ (variation by 0.5) \\
\hline
\end{tabular}

Available indicators of liberalisation arising from official sources are mostly indicator variables being either 0 or 1 . However, such indicator variables do not allow to differentiate the varying levels of control or to capture a decreasing level of control over time. Measuring a level of integration for each year is therefore a better solution from an econometric point of view. Quinn $(1997,2000)$ has constructed such a yearly index of openness on the basis of those restrictions published by the IMF since the 1950s. This index is scaled from 0 (highest degree of restrictions) up to 14 (highest degree of liberalisation) and aggregates the different indicators of liberalisation progress in seven specified fields (capital in - and outflows, imand exports of goods and of services as well as international conventions of liberalisation) with a respective degree of liberalisation between 0.5 and 2 .

Quinn weighs quantitative restrictions of imports for example the highest (i.e. he attributes the lowest partial liberalisation index of 0 in case of full and 0.5 in case of partly quantitative restrictions), existence of laws requiring the approval of international transactions are scored 1 , taxes 1.5 and finally free trade 2. With regard to capital account liberalisation, Quinn attributes 0 in case of required approval for capital transactions which are rarely granted, 0.5 (1) in case of occasional (frequent) approval and finally 1.5 in case of taxing measurements (without the need of an official approval). A subindex of the overall liberalisation index is a financial liberalisation indicator ranging on a score between 0 and 4 which is aggregated from restrictions of capital inward and outward flows in the way explained above. All named potential indicators, however, are only available at country, not regional, level, which has to be taken into account in econometric analysis. Detailed restrictions for Luxembourg are not available as Luxembourg and Belgium are part of a common monetary union since the 1950s. In our analysis the „Quinn-indicator" for Luxembourg is therefore naturally set equal to the one of Belgium. 
Table A4: Investment specialisation levels in EU regions in 1985-94 in relation to national countries (Standardised Gini-coefficients/ 17 sectors)

\begin{tabular}{|c|c|c|c|c|c|c|c|}
\hline \multirow{2}{*}{\multicolumn{2}{|c|}{\begin{tabular}{|l|} 
France \\
Nuts 2, 1986 to 1992 \\
\end{tabular}}} & \multirow{2}{*}{\multicolumn{2}{|c|}{\begin{tabular}{|l|} 
Italy \\
Nuts 2
\end{tabular}}} & \multicolumn{2}{|l|}{ Belgium } & \multicolumn{2}{|l|}{ United Kingdom } \\
\hline & & & & Nuts 2 & & & \\
\hline & 0.626 & Valle d'Aosta & 0.538 & Bruxelles-capitale & 0.734 & \multicolumn{2}{|c|}{ Note: Sectoral availability is strongly } \\
\hline Corse & 0.512 & Basilicata & 0.497 & Luxembourg (B) & 0.666 & \multirow{3}{*}{\multicolumn{2}{|c|}{$\begin{array}{l}\text { varying in Belgium from } 4 \text { to } 11 \text { sectors. } \\
\text { However, mostly } 11 \text { sectors are } \\
\text { included. }\end{array}$}} \\
\hline Franche-Comté & 0.389 & Molise & 0.481 & Namur & 0.656 & & \\
\hline Bretagne & 0.368 & Sardegna & 0.427 & Brabant Wallon & 0.557 & & \\
\hline Haute-Normandie & 0.353 & Calabria & 0.422 & Hainaut & 0.549 & \multirow{5}{*}{\multicolumn{2}{|c|}{$\begin{array}{l}\text { Due to a change in sectoral availability } \\
\text { of British data ( } 9 \text { sectors prior to } 1987, \\
4 \text { since } 1988 \text { ), results for the time } \\
\text { since } 1988 \text { are rather primarily and not } \\
\text { directly comparable to prior years. }\end{array}$}} \\
\hline Auvergne & 0.339 & Sicilia & 0.389 & Antwerpen & 0.500 & & \\
\hline Champagne-Ardenne & 0.329 & Umbria & 0.355 & Vlaams Brabant & 0.466 & & \\
\hline Provence-Alpes-Côte d'Azur & 0.323 & Lazio & 0.355 & West-Vlaanderen & 0.455 & & \\
\hline Limousin & 0.322 & Trentino-Alto Adige & 0.336 & Limburg (B) & 0.420 & & \\
\hline Poitou-Charentes & 0.314 & Liguria & 0.331 & Liège & 0.399 & \multirow{2}{*}{\multicolumn{2}{|c|}{$\begin{array}{l}\text { Data has not been available for three of } \\
\text { the eleven NUTS 1-regions. }\end{array}$}} \\
\hline Languedoc-Rousillon & 0.309 & Puglia & 0.292 & Oost-Vlaanderen & 0.388 & & \\
\hline Ile de France & 0.288 & Abruzzo & 0.286 & & & & \\
\hline Picardie & 0.278 & Campania & 0.285 & & & & \\
\hline Nord - Pas-de-Calais & 0.266 & Piemonte & 0.277 & & & & \\
\hline Alsace & 0.244 & Marche & 0.272 & & & & \\
\hline Aquitaine & 0.240 & Emilia-Romagna & 0.269 & & & & \\
\hline Midi-Pyrénées & 0.240 & Friuli-Venezia Giulia & 0.250 & & & & \\
\hline Bourgogne & 0.221 & Lombardia & 0.225 & & & & \\
\hline Pays de la Loire & 0.221 & Toscana & 0.218 & & & & \\
\hline Rhône-Alpes & 0.215 & Veneto & 0.198 & & & & \\
\hline Lorraine & 0.212 & & & & & & \\
\hline Centre (F) & 0.210 & & & & & & \\
\hline \multicolumn{2}{|l|}{ Nuts 1, 1986 to 1992} & \multicolumn{2}{|l|}{ Nuts 1} & \multicolumn{2}{|l|}{ Nuts 1} & \multicolumn{2}{|l|}{ Nuts 1,1985 to 1987} \\
\hline Ile de France & 0.288 & Sardegna & 0.427 & Bruxelles-capitale & 0.734 & INorthern Ireland & 0.533 \\
\hline Méditerranée & 0.281 & Sicilia & 0.389 & Région Wallonne & 0.413 & Wales & 0.363 \\
\hline Ouest & 0.267 & Lazio & 0.355 & Vlaams Gewest & 0.252 & West Midlands & 0.316 \\
\hline Nord - Pas-de-Calais & 0.266 & Sud & 0.293 & & & East Anglia & 0.313 \\
\hline Bassin Parisien & 0.213 & Abruzzo-Molise & 0.289 & & & Scotland & 0.270 \\
\hline Centre-Est & 0.207 & Campania & 0.285 & & & Yorkshire and the Humber & 0.255 \\
\hline Sud-Ouest & 0.188 & Emilia-Romagna & 0.269 & & & East Midlands & 0.154 \\
\hline Est $(\mathrm{F})$ & 0.180 & Lombardia & 0.225 & & & South West & 0.135 \\
\hline & & Nord Ovest & 0.210 & & & South East & n.a. \\
\hline & & Centro (I) & 0.177 & & & North & n.a. \\
\hline & & Nord Est & 0.173 & & & North West & n.a. \\
\hline
\end{tabular}


Table A5: Investment specialisation levels in EU regions in 1985 to 1994 in relation to EU as a whole (Standardised Gini-coefficients/ 17 sectors)

\begin{tabular}{|c|c|c|c|c|c|c|c|}
\hline \multirow{2}{*}{\multicolumn{2}{|c|}{\begin{tabular}{|l|} 
France \\
Nuts 2, 1986 to 1992 \\
\end{tabular}}} & \multicolumn{2}{|l|}{ Italy } & \multicolumn{2}{|l|}{ Belgium } & \multicolumn{2}{|l|}{ United Kingdom } \\
\hline & & \multicolumn{2}{|l|}{ Nuts 2} & \multicolumn{2}{|l|}{ Nuts 2} & & \\
\hline \begin{tabular}{|l} 
Basse-Normandie \\
\end{tabular} & 0.672 & Basilicata & 0.607 & Luxembourg (B) & 0.725 & \multirow{2}{*}{\multicolumn{2}{|c|}{$\begin{array}{l}\text { Note: Sectoral availability is strongly } \\
\text { varying in Belqium from } 4 \text { to } 11 \text { sectors. }\end{array}$}} \\
\hline \begin{tabular}{|l|} 
Corse \\
\end{tabular} & 0.596 & Calabria & 0.590 & Bruxelles-capitale & 0.719 & & \\
\hline lle de France & 0.475 & Molise & 0.579 & Namur & 0.691 & \multirow{2}{*}{\multicolumn{2}{|c|}{$\begin{array}{l}\text { However, mostly } 11 \text { sectors are } \\
\text { included. }\end{array}$}} \\
\hline Bretagne & 0.474 & Valle d'Aosta & 0.572 & Hainaut & 0.563 & & \\
\hline Provence-Alpes-Côte d'Azur & 0.473 & Sicilia & 0.566 & Brabant Wallon & 0.538 & \multirow{3}{*}{\multicolumn{2}{|c|}{$\begin{array}{l}\text { Due to a change in sectoral availability } \\
\text { of British data (9 sectors prior to } 1987 \\
4 \text { since 1988), results for the time }\end{array}$}} \\
\hline Languedoc-Rousillon & 0.454 & Sardegna & 0.562 & Antwerpen & 0.503 & & \\
\hline Franche-Comté & 0.454 & Lazio & 0.507 & West-Vlaanderen & 0.491 & & \\
\hline Auvergne & 0.446 & Puglia & 0.492 & Liège & 0.479 & \multirow{2}{*}{\multicolumn{2}{|c|}{$\begin{array}{l}\text { since } 1988 \text { are rather primarily and not } \\
\text { directly comparable to prior years. }\end{array}$}} \\
\hline Poitou-Charentes & 0.424 & Umbria & 0.485 & Vlaams Brabant & 0.466 & & \\
\hline Haute-Normandie & 0.410 & Liguria & 0.454 & Limburg (B) & 0.446 & \multirow{2}{*}{\multicolumn{2}{|c|}{$\begin{array}{l}\text { Data has not been available for three of } \\
\text { the eleven NUTS 1-regions. }\end{array}$}} \\
\hline Limousin & 0.406 & Marche & 0.443 & Oost-Vlaanderen & 0.441 & & \\
\hline Champagne-Ardenne & 0.405 & Abruzzo & 0.442 & & & & \\
\hline Aquitaine & 0.400 & Trentino-Alto Adige & 0.439 & & & & \\
\hline Midi-Pyrénées & 0.381 & Campania & 0.428 & & & \multicolumn{2}{|l|}{ Monoregional countries } \\
\hline Centre (F) & 0.379 & Friuli-Venezia Giulia & 0.390 & & & Denmark & 0.380 \\
\hline Pays de la Loire & 0.364 & Emilia-Romagna & 0.386 & & & Ireland & 0.513 \\
\hline Lorraine & 0.334 & Toscana & 0.382 & & & Luxembourg & 0.432 \\
\hline Bourgogne & 0.333 & Veneto & 0.375 & & & & \\
\hline Picardie & 0.315 & Piemonte & 0.373 & & & & \\
\hline Rhône-Alpes & 0.311 & Lombardia & 0.311 & & & & \\
\hline Alsace & 0.310 & & & & & & \\
\hline Nord - Pas-de-Calais & 0.303 & & & & & & \\
\hline \multicolumn{2}{|l|}{ Nuts 1, 1986 to 1992} & \multicolumn{2}{|l|}{ Nuts 1} & \multicolumn{2}{|l|}{ Nuts 1} & \multicolumn{2}{|l|}{ Nuts 1,1985 to 1987} \\
\hline Ile de France & 0.475 & Sicilia & 0.566 & Bruxelles-capitale & 0.719 & Yorkshire and the Humber & 0.471 \\
\hline Méditerranée & 0.445 & Sardegna & 0.562 & Région Wallonne & 0.439 & Wales & 0.449 \\
\hline Ouest & 0.405 & Lazio & 0.507 & Vlaams Gewest & 0.271 & West Midlands & 0.441 \\
\hline Sud-Ouest & 0.361 & Sud & 0.500 & & & East Midlands & 0.435 \\
\hline Bassin Parisien & 0.327 & Abruzzo-Molise & 0.446 & & & East Anglia & 0.424 \\
\hline \begin{tabular}{|l} 
Centre-Est \\
\end{tabular} & 0.316 & Campania & 0.428 & & & Scotland & 0.399 \\
\hline Nord - Pas-de-Calais & 0.303 & Emilia-Romagna & 0.386 & & & South West & 0.390 \\
\hline \multirow[t]{4}{*}{ Est (F) } & 0.289 & Centro (I) & 0.375 & & & Northern Ireland & 0.378 \\
\hline & & Nord Est & 0.359 & & & North & n.a. \\
\hline & & Nord Ovest & 0.344 & & & North West & n.a. \\
\hline & & Lombardia & 0.311 & & & South East & n.a. \\
\hline
\end{tabular}


Table A6: Characteristics of most/least specialised NUTS 2-regions - specialisation relative to national structure (average 1985-94 unless indicated in brackets)

\begin{tabular}{|l|l|l|l|l|l|l|l|l|l|}
\hline Region & $\begin{array}{l}\text { Index of } \\
\text { investment } \\
\text { specialisa- } \\
\text { tion (GCCF) }\end{array}$ & $\begin{array}{l}\text { Index of } \\
\text { employment } \\
\text { specialisation }\end{array}$ & $\begin{array}{l}\text { Regional } \\
\text { per capita } \\
\text { GDP in } \\
\text { Mio ECU } \\
\text { per 1000 }\end{array}$ & $\begin{array}{l}\text { GFCF in billion } \\
\text { ECU }\end{array}$ & $\begin{array}{l}\text { GFCF } \\
\text { in \% of } \\
\text { GDP }\end{array}$ & $\begin{array}{l}\text { Num- } \\
\text { ber of } \\
\text { patents } \\
\text { [89-94] }\end{array}$ & $\begin{array}{l}\text { Employ- } \\
\text { ment } \\
\text { share } \\
\text { (in\%) }\end{array}$ & $\begin{array}{l}\text { Unemploy- } \\
\text { ment rate } \\
\text { (in \% of } \\
\text { working } \\
\text { population) }\end{array}$ & $\begin{array}{l}\text { Net } \\
\text { migration } \\
\text { rate 1997 in } \\
\% \text { of } \\
\text { population }\end{array}$ \\
\hline NUTS 2, most specialised regions \\
\hline Bruxelles-capitale
\end{tabular}


Table A7: Characteristics of most/least specialised NUTS 2 regions - specialisation relative to EU structure (average 1985-94 unless indicated in brackets)

\begin{tabular}{|c|c|c|c|c|c|c|c|c|c|}
\hline Region & $\begin{array}{l}\text { Index of } \\
\text { investment } \\
\text { specialisa- } \\
\text { tion } \\
\text { (GCCFEU) }\end{array}$ & $\begin{array}{l}\text { Index of } \\
\text { employment } \\
\text { specialisa- } \\
\text { tion }\end{array}$ & $\begin{array}{l}\text { Regional } \\
\text { per capita } \\
\text { GDP in } \\
\text { Mio ECU } \\
\text { per } 1000\end{array}$ & $\begin{array}{l}\text { GFCF in billion } \\
\text { ECU }\end{array}$ & $\begin{array}{l}\text { GFCF } \\
\text { in \% of } \\
\text { GDP }\end{array}$ & \begin{tabular}{|l}
$\begin{array}{l}\text { Num- } \\
\text { ber of } \\
\text { patents } \\
{[89-94]}\end{array}$ \\
\end{tabular} & $\begin{array}{l}\text { Employ- } \\
\text { ment } \\
\text { share } \\
(\text { in\%) }\end{array}$ & $\begin{array}{l}\text { Unemploy- } \\
\text { ment rate } \\
\text { (in \% of } \\
\text { working } \\
\text { population) }\end{array}$ & $\begin{array}{l}\text { Net } \\
\text { migration } \\
\text { rate 1997 } \\
\text { in \%o of } \\
\text { population }\end{array}$ \\
\hline \multicolumn{10}{|c|}{ NUTS 2, most specialised regions } \\
\hline Bruxelles-capitale & 0.719 & 0.515 [85-92] & 23.17 & n.a. & n.a. & 71 & 18.0 & 10.82 & 0.1 \\
\hline Luxembourg (B) & 0.725 & 0.542 [85-92] & 12.57 & n.a. & n.a. & 6 & 2.1 & 7.52 & 2.8 \\
\hline Basilicata & 0.607 & 0.648 & 8.62 & 1.462 & 28.0 & 1 & 0.9 & 16.67 & 3.1 \\
\hline Calabria & 0.590 & 0.697 & 7.90 & 4.222 & 25.56 & 3 & 2.9 & 19.31 & -3.2 \\
\hline \multicolumn{10}{|c|}{ NUTS 2, least specialised regions } \\
\hline Limburg (B) & 0.446 & 0.302 [85-92] & 14.05 & n.a. & n.a. & 21 & 6.7 & 10.34 & 0 \\
\hline Oost-Vlaandern & 0.441 & 0.397 [85-92] & 14.06 & n.a. & n.a. & 71 & 12.0 & 6.67 & 1.5 \\
\hline Alsace & $0.310[86-92]$ & 0.247 [85-90] & 16.2 & $6.058[86-92]$ & 23.45 & 215 & 2.9 & 6.28 & 1.1 \\
\hline \multicolumn{10}{|c|}{ Region including national capital } \\
\hline Ile de France & $0.475[86-92]$ & $0.277[85-89]$ & 24.30 & $52.066[86-92]$ & 20.61 & 2232 & 22.6 & 8.29 & -4.9 \\
\hline Lazio & 0.507 & 0.359 & 15.18 & 16.626 & 21.24 & 147 & 9.3 & 9.75 & 5.2 \\
\hline South-East & n.a. & n.a. & 15.08 & n.a. & n.a. & 779 & 33.8 & 7.86 & 25.0 \\
\hline
\end{tabular}


Table A8a: Correlation matrix NUTS 1-level: multicollinear variables

\begin{tabular}{r|rrrrrr|}
\hline gdp & 1 & & & & & \\
gfcf & 0.9456 & 1 & & & & \\
vafp & 0.9984 & 0.9555 & 1 & & & \\
pop & 0.8535 & 0.8267 & 0.8574 & 1 & & \\
totem & 0.9383 & 0.877 & 0.936 & 0.9496 & 1 & \\
coe & 0.9826 & 0.9044 & 0.973 & 0.8456 & 0.9349 & 1 \\
\hline
\end{tabular}

Table A8b: Correlation matrix NUTS 2-level: multicollinear variables

\begin{tabular}{r|rrrrrr|}
\hline & gdp & gfcf & vafp & pop & totem & coe \\
\hline gdp & 1 & & & & & \\
gff & 0.9039 & 1 & & & & \\
vafp & 0.9994 & 0.9027 & 1 & & & \\
pop & 0.9118 & 0.8473 & 0.9138 & 1 & & \\
totem & 0.9667 & 0.8755 & 0.967 & 0.9726 & 1 & \\
coe & 0.9936 & 0.9217 & 0.9906 & 0.9129 & 0.9652 & 1 \\
\hline
\end{tabular}

Table A9a: Correlation matrix NUTS 1-level: explanatory variables

\begin{tabular}{|c|c|c|c|c|c|c|c|c|}
\hline & gccf & gccfeu & gdp & zentrreg & quinn_openn & uewp & poden & centr \\
\hline gccf & 1 & & & & & & & \\
\hline gccfeu & 0.6548 & 1 & & & & & & \\
\hline gdp & -0.37 & -0.3161 & 1 & & & & & \\
\hline zentrreg & 0.4594 & 0.4739 & 0.2648 & 1 & & & & \\
\hline quinn_openn & -0.0239 & 0.0361 & 0.1657 & -0.0209 & 1 & & & \\
\hline uewp & 0.4424 & 0.4081 & -0.4353 & -0.0743 & -0.0676 & 1 & & \\
\hline poden & 0.626 & 0.5095 & -0.1072 & 0.61 & -0.0669 & -0.0076 & 1 & \\
\hline centr & -0.0615 & -0.0517 & -0.049 & -0.4859 & 0.0721 & 0.2763 & -0.3271 & 1 \\
\hline
\end{tabular}

Table A9b: Correlation matrix NUTS 2-level: explanatory variables

\begin{tabular}{|c|c|c|c|c|c|c|c|c|}
\hline & gccf & gccfeu & gdp & zentrreg & quinn_openn & uewp & poden & centr \\
\hline gccf & 1 & & & & & & & \\
\hline gccfeu & 0.8978 & 1 & & & & & & \\
\hline gdp & -0.391 & -0.3152 & 1 & & & & & \\
\hline zentrreg & 0.153 & 0.2018 & 0.4548 & 1 & & & & \\
\hline quinn_openn & -0.0473 & 0.0147 & 0.1289 & -0.0093 & 1 & & & \\
\hline uewp & 0.1716 & 0.2367 & -0.1423 & -0.0344 & -0.0671 & 1 & & \\
\hline poden & 0.3285 & 0.2547 & 0.0684 & 0.618 & -0.0448 & -0.0345 & 1 & \\
\hline centr & -0.2077 & -0.0631 & 0.0062 & -0.3231 & 0.0886 & 0.4613 & -0.2537 & 1 \\
\hline
\end{tabular}


Table A10: Pooled regressions including time-specific dummies

\begin{tabular}{|c|c|c|c|c|c|c|c|}
\hline & NUTS 2 & NUTS 2 & NUTS 1 & NUTS 2 & NUTS 2 & NUTS 1 & NUTS 1 \\
\hline & gccfeu & gccfeu & gccfeu & gccf & gccf & gccf & gccf \\
\hline & $1985-94$ & $1989-94$ & $1985-94$ & $1985-94$ & $1989-94$ & $1985-94$ & $1989-94$ \\
\hline \multirow[t]{2}{*}{ constant } & 0.3696 & 0.0604 & 0.3790 & 0.5959 & 0.2037 & 0.1669 & -0.2527 \\
\hline & 3.51 & 0.47 & 3.95 & 4.60 & 1.29 & 1.43 & -1.97 \\
\hline \multirow[t]{2}{*}{ gdp } & -0.0009 & -0.0016 & -0.0004 & -0.0012 & -0.0023 & -0.0008 & -0.0017 \\
\hline & -7.16 & -5.28 & -4.25 & -7.49 & -6.50 & -5.81 & -5.89 \\
\hline \multirow[t]{2}{*}{ zentrreg } & 0.1217 & 0.0790 & 0.1020 & 0.1056 & 0.0836 & 0.1543 & 0.1311 \\
\hline & 6.57 & 3.78 & 7.08 & 3.24 & 2.08 & 6.26 & 4.66 \\
\hline \multirow[t]{2}{*}{ uewp } & 0.0088 & 0.0085 & 0.0074 & 0.0045 & 0.0040 & 0.0091 & 0.0060 \\
\hline & 8.47 & 6.57 & 6.87 & 3.71 & 2.76 & 6.75 & 4.07 \\
\hline \multirow[t]{2}{*}{ poden } & 0.0135 & 0.0277 & 0.0355 & 0.0272 & 0.0394 & 0.0506 & 0.0568 \\
\hline & 2.28 & 3.74 & 8.00 & 3.49 & 4.17 & 8.56 & 8.42 \\
\hline \multirow[t]{2}{*}{ area } & -0.0032 & -0.0015 & -0.0003 & -0.0057 & -0.0043 & -0.0002 & 0.0004 \\
\hline & -8.63 & -3.12 & -2.00 & -10.99 & -5.85 & -1.07 & 2.00 \\
\hline \multirow[t]{2}{*}{ quinn_openn } & 0.0051 & 0.0274 & -0.0029 & -0.0110 & 0.0174 & 0.0025 & 0.0375 \\
\hline & 0.69 & 3.05 & -0.44 & -1.21 & 1.56 & 0.31 & 4.06 \\
\hline \multirow[t]{2}{*}{ pat } & & 0.0001 & & & 0.0002 & & 0.0001 \\
\hline & & 3.09 & & & 4.06 & & 4.10 \\
\hline \multirow[t]{2}{*}{ centr } & 0.0517 & & 0.0615 & 0.0159 & -0.0109 & 0.0762 & 0.0424 \\
\hline & 3.02 & & 3.09 & 0.80 & -0.37 & 3.49 & 1.62 \\
\hline \multirow[t]{2}{*}{ year_1985 } & 0.0156 & -- & -0.0313 & -0.0630 & -- & -0.0104 & -- \\
\hline & 0.44 & & -1.00 & -1.49 & & -0.28 & \\
\hline \multirow[t]{2}{*}{ year_1986 } & -0.0013 & -- & -0.0287 & -0.0552 & -- & -0.0204 & -- \\
\hline & -0.04 & & -0.97 & -1.44 & & -0.58 & \\
\hline \multirow[t]{2}{*}{ year_1987 } & -0.0086 & -- & -0.0291 & -0.0499 & -- & -0.0143 & -- \\
\hline & -0.27 & & -0.98 & -1.3 & & -0.41 & \\
\hline \multirow[t]{2}{*}{ year_1988 } & -0.0142 & -- & -0.0167 & -0.0517 & -- & -0.0256 & -- \\
\hline & -0.48 & & -0.60 & -1.45 & & -0.77 & \\
\hline \multirow[t]{2}{*}{ year_1989 } & -0.0004 & 0.0612 & -0.0081 & -0.0501 & 0.0307 & -0.0157 & 0.0575 \\
\hline & -0.01 & 1.90 & -0.29 & -1.40 & 0.80 & -0.47 & 1.78 \\
\hline \multirow[t]{2}{*}{ year_1990 } & 0.0031 & 0.0239 & 0.0001 & -0.0133 & 0.0148 & -0.0026 & 0.0153 \\
\hline & 0.14 & 1.09 & 0.00 & -0.52 & 0.59 & -0.10 & 0.63 \\
\hline \multirow[t]{2}{*}{ year_1991 } & -0.0083 & 0.0022 & -0.0014 & -0.0133 & 0.0018 & 0.0035 & 0.0090 \\
\hline & -0.41 & 0.11 & -0.06 & -0.56 & 0.08 & 0.14 & 0.40 \\
\hline \multirow[t]{2}{*}{ year_1992 } & 0.0190 & 0.0269 & 0.0090 & 0.0101 & 0.0230 & 0.0152 & 0.0192 \\
\hline & 0.94 & 1.36 & 0.42 & 0.42 & 1.02 & 0.60 & 0.86 \\
\hline \multirow[t]{2}{*}{ year_1993 } & 0.0068 & 0.0119 & 0.0134 & -0.0020 & 0.0057 & 0.0049 & 0.0044 \\
\hline & 0.31 & 0.47 & 0.60 & -0.08 & 0.24 & 0.19 & 0.19 \\
\hline no. obs. & 487 & 282 & 292 & 463 & 267 & 268 & ol \\
\hline SSR OLS & 3.9062 & 2.1079 & 1.4157 & 4.756 & 2.347 & 1.492 & 0.619 \\
\hline Log Likeli & 484.0330 & 290.2260 & 363.7200 & 402.9230 & 253.1346 & 315.2989 & 200.7544 \\
\hline Prob Chi $^{2}$ & 0.0000 & 0.0000 & 0.0000 & 0.0000 & 0.0000 & 0.0000 & 0.0000 \\
\hline AIC & -1.918 & -1.966 & -2.375 & -1.667 & -1.761 & -2.226 & -2.42 \\
\hline
\end{tabular}

Note: see Table 1a. 
Table A11: IV-estimates and dynamic specification results, 1985-94, pooled regressions

\begin{tabular}{|c|c|c|c|c|c|c|c|c|c|c|c|c|c|}
\hline & NUTS 2 & \begin{tabular}{l|} 
NUTS 2 \\
\end{tabular} & NUTS 2 & \begin{tabular}{l|} 
NUTS 2 \\
\end{tabular} & NUTS 1 & NUTS 1 & \begin{tabular}{l|} 
NUTS 1 \\
\end{tabular} & \begin{tabular}{l|} 
NUTS 1 \\
\end{tabular} & & NUTS 2 & NUTS 2 & NUTS 2 & NUTS 2 \\
\hline IV 2SLS & gecf & gecf & gccfeu & gccfeu & gccf & gccf & gccfeu & gccfeu & dyn. model & gccf & gccf & gccfeu & gccfeu \\
\hline \multirow[t]{4}{*}{\begin{tabular}{|l|} 
constant \\
\end{tabular}} & 0.3782 & 0.2237 & 0.3266 & 0.2943 & 0.0633 & 0.0349 & 0.2676 & 0.2835 & constant & 0.0450 & 0.0285 & 0.0253 & 0.0387 \\
\hline & 8.00 & 4.85 & 8.17 & 7.31 & 1.19 & 0.67 & 6.00 & 6.17 & & 1.51 & 0.94 & 0.94 & 1.36 \\
\hline & & & & & & & & & $\operatorname{gccf}(e u) A R(1)$ & 0.8159 & 0.7750 & 0.8101 & 0.7623 \\
\hline & & & & & & & & & & 27.87 & 23.75 & 26.51 & 23.24 \\
\hline \multirow[t]{2}{*}{ gdp (IV) } & -0.0012 & -0.0010 & -0.0009 & -0.0009 & -0.0008 & -0.0009 & -0.0004 & -0.0005 & gdp & -0.0003 & -0.0003 & -0.0002 & -0.0002 \\
\hline & -6.92 & -6.71 & -6.67 & -6.85 & -5.42 & -5.89 & -4.01 & -3.71 & & -2.48 & -2.61 & -2.05 & -2.58 \\
\hline \multirow[t]{2}{*}{ zentrreg } & 0.1010 & 0.1785 & 0.1204 & 0.2371 & 0.1558 & 0.2029 & 0.0985 & 0.1563 & zentrreg & 0.0219 & 0.0404 & 0.0186 & 0.0602 \\
\hline & 2.86 & 5.42 & 6.00 & 8.00 & 5.72 & 7.77 & 6.34 & 6.36 & & 1.06 & 1.85 & 1.45 & 2.89 \\
\hline \multirow[t]{2}{*}{ uewp (IV) } & 0.0044 & 0.0056 & 0.0089 & 0.0075 & 0.0087 & 0.0081 & 0.0072 & 0.0061 & uewp & 0.0004 & 0.0009 & 0.0014 & 0.0014 \\
\hline & 3.27 & 4.51 & 7.72 & 6.74 & 5.78 & 5.72 & 6.08 & 4.59 & & 0.54 & 1.17 & 2.02 & 1.95 \\
\hline \multirow[t]{2}{*}{ poden } & 0.0278 & 0.0031 & 0.0140 & -0.0141 & 0.0504 & 0.0253 & 0.0353 & 0.0315 & poden & 0.0063 & 0.0025 & 0.0058 & -0.0019 \\
\hline & 3.31 & 0.39 & 2.19 & -1.95 & 7.77 & 3.62 & 7.42 & 4.78 & & 1.26 & 0.50 & 1.48 & -0.40 \\
\hline \multirow[t]{2}{*}{ area } & -0.0055 & -0.0039 & -0.0030 & -0.0020 & -0.0001 & -0.0002 & -0.0003 & 0.0002 & area & -0.0009 & -0.0009 & -0.0002 & -0.0004 \\
\hline & $\begin{array}{l}-9.84 \\
\end{array}$ & $\mid-6.20$ & -7.59 & -3.46 & -0.67 & \begin{tabular}{|c|}
-0.76 \\
\end{tabular} & $\mid-1.64$ & 0.86 & & -2.40 & $\mid-2.08$ & -0.95 & -1.00 \\
\hline \multirow[t]{2}{*}{ quinn_openn } & 0.0046 & 0.0073 & 0.0084 & 0.0078 & 0.0107 & 0.0110 & 0.0060 & 0.0064 & quinn_openn & 0.0031 & 0.0039 & 0.0043 & 0.0045 \\
\hline & 1.31 & 2.24 & 2.78 & 2.75 & 2.61 & 2.85 & 1.75 & 1.89 & & 1.50 & 1.85 & 2.35 & 2.41 \\
\hline \multirow[t]{2}{*}{ centr } & 0.0092 & 0.1178 & 0.0480 & 0.1269 & 0.0791 & 0.1432 & 0.0548 & 0.0353 & centr & 0.0046 & 0.0268 & 0.0113 & 0.0342 \\
\hline & 0.43 & 5.27 & 2.58 & 6.31 & 3.26 & 5.86 & 2.53 & 1.53 & & 0.36 & 1.81 & 0.99 & 2.48 \\
\hline \multirow[t]{2}{*}{ dum_fra } & & 0.0295 & & -0.0196 & & 0.0180 & --- & -0.0485 & dum_fra & & 0.0092 & & -0.0021 \\
\hline & & 2.33 & & -1.72 & & 1.09 & & -3.14 & & & 1.13 & & -0.29 \\
\hline \multirow[t]{2}{*}{ dum_bel } & & 0.1631 & & 0.0963 & & 0.1342 & --- & -0.0426 & dum_bel & & 0.0325 & & 0.0213 \\
\hline & & 9.76 & & 6.41 & & 6.46 & & -2.17 & & & 2.70 & & 2.06 \\
\hline \multirow[t]{2}{*}{ dum_ire } & & --- & & -0.0353 & & --- & --- & -0.0753 & dum_ire & & --- & & 0.0089 \\
\hline & & & & -0.63 & & & & -2.01 & & & & & 0.24 \\
\hline \multirow[t]{2}{*}{ dum_lux } & & --- & & -0.2111 & & --- & --- & -0.1156 & dum_lux & & --- & & -0.0822 \\
\hline & & & & -4.77 & & & & -2.92 & & & & & -2.79 \\
\hline \multirow[t]{2}{*}{ dum_den } & & --- & & -0.1249 & & --- & --- & -0.1457 & dum_den & & --- & & -0.0316 \\
\hline & & & & -2.80 & & & & -4.34 & & & & & -1.07 \\
\hline \multirow[t]{3}{*}{ dum_ukd } & & --- & & --- & & 0.0001 & --- & 0.0069 & dum_ukd & & --- & & --- \\
\hline & & & & & & 0.01 & & 0.59 & & & & & \\
\hline & & & & & & & & & & & & & \\
\hline no. obs. & 410 & 410 & 431 & 431 & 238 & 238 & 259 & 259 & no. obs. & 410 & 410 & 431 & 431 \\
\hline SSR & 4.311 & 3.473 & 3.558 & 2.937 & 1.380 & 1.144 & 1.258 & 1.096 & Log Likeli & 569.88 & 573.73 & 630.63 & 638.50 \\
\hline Prob F & 0.0000 & 0.0000 & \begin{tabular}{ll|l}
0.0000 \\
\end{tabular} & 0.0000 & 0.0000 & 0.0000 & 0.0000 & 0.0000 & Prob Chi2 & 0.0000 & 0.0000 & 0.0000 & 0.0000 \\
\hline
\end{tabular}

Note: GDP and UEWP have been instrumented by their first lag. T-values are given in the IV-estimates, z-values for the dynamic model. 
Table A12: Logistic transformation and impact of capital market integration

\begin{tabular}{|c|c|c|c|c|c|c|c|c|c|}
\hline & NUTS 2 & NUTS 1 & NUTS 2 & NUTS 1 & & NUTS 2 & NUTS 1 & NUTS 2 & NUTS 1 \\
\hline & \multicolumn{4}{|c|}{ logit terms estimation } & & \multicolumn{4}{|c|}{ capital market integration } \\
\hline & gccf & gccf & gccfeu & gccfeu & & gccf & gccf & gccfeu & gccfeu \\
\hline & $1985-94$ & $1985-94$ & $1985-94$ & $1985-94$ & & 1985-94 & 1985-94 & 1985-94 & 1985-94 \\
\hline \multirow[t]{2}{*}{ constant } & -1.2124 & -2.2014 & -0.7781 & -0.9509 & constant & 0.2501 & 0.0689 & 0.3254 & 0.2809 \\
\hline & -6.61 & -8.46 & -4.94 & -5.40 & & 5.81 & 1.51 & 8.71 & 6.95 \\
\hline \multirow[t]{2}{*}{ gdp } & -0.0047 & -0.0042 & -0.0041 & -0.0021 & gdp & -0.0010 & -0.0008 & -0.0009 & -0.0005 \\
\hline & -7.45 & -5.38 & -7.25 & -3.84 & & -7.21 & -6.07 & -7.28 & -3.76 \\
\hline \multirow[t]{2}{*}{ zentrreg } & 0.8406 & 1.0113 & 0.9874 & 0.6541 & zentrreg & 0.1785 & 0.1967 & 0.2328 & 0.1552 \\
\hline & 6.2 & 7.5 & 8.24 & 6.71 & & 5.83 & 8.23 & 8.44 & 6.81 \\
\hline \multirow[t]{2}{*}{ uewp } & 0.0259 & 0.0436 & 0.0307 & 0.0277 & uewp & 0.0053 & 0.0084 & 0.0073 & 0.0066 \\
\hline & 5.35 & 6.21 & 7.22 & 5.50 & & 4.86 & 6.74 & 7.50 & 5.62 \\
\hline \multirow[t]{2}{*}{ poden } & 0.0085 & 0.0914 & -0.0511 & 0.1461 & poden & 0.0036 & 0.0273 & -0.0132 & 0.0323 \\
\hline & 0.26 & 2.52 & -1.75 & 5.56 & & 0.48 & 4.24 & -1.96 & 5.26 \\
\hline \multirow[t]{2}{*}{ area } & -0.0183 & -0.0006 & -0.0082 & 0.0010 & area & -0.0040 & -0.0002 & -0.0021 & 0.0002 \\
\hline & -7.12 & -0.53 & -3.62 & 1.22 & & -6.88 & -0.90 & -3.94 & 1.04 \\
\hline \multirow[t]{2}{*}{ quinn_openn } & 0.0333 & 0.0538 & 0.0282 & 0.0282 & quinn_ca & 0.0192 & 0.0281 & 0.0200 & 0.0207 \\
\hline & 2.52 & 2.72 & 2.50 & 2.12 & & 1.75 & 2.34 & 2.11 & 1.96 \\
\hline \multirow[t]{2}{*}{ centr } & 0.5243 & 0.6332 & 0.5121 & 0.1440 & centr & 0.1179 & 0.1352 & 0.1238 & 0.0359 \\
\hline & 5.74 & 5.05 & 6.35 & 1.59 & & 5.72 & 6.08 & 6.65 & 1.69 \\
\hline \multirow[t]{2}{*}{ dum_fra } & 0.1240 & 0.0558 & -0.0887 & -0.2172 & dum_fra & 0.0291 & 0.0137 & -0.0185 & -0.0480 \\
\hline & 2.42 & 0.66 & -1.96 & -3.58 & & 2.43 & 0.89 & -1.72 & -3.30 \\
\hline \multirow[t]{2}{*}{ dum_bel } & 0.7056 & 0.6396 & 0.3992 & -0.1964 & dum_bel & 0.1602 & 0.1274 & 0.0909 & -0.0437 \\
\hline & 10.29 & 5.91 & 6.58 & -2.51 & & 10.35 & 6.64 & 6.51 & -2.39 \\
\hline \multirow[t]{2}{*}{ dum_ukd } & --- & -0.0846 & --- & -0.0040 & dum_ukd & --- & -0.0092 & --- & -0.0071 \\
\hline & & \begin{tabular}{|l|}
-1.33 \\
\end{tabular} & & -0.09 & & & -0.80 & & -0.64 \\
\hline \multirow[t]{2}{*}{ dum_ire } & --- & --- & -0.2406 & -0.4164 & dum_ire & --- & --- & -0.0455 & -0.0925 \\
\hline & & & \begin{tabular}{|l|}
-1.07 \\
\end{tabular} & -2.80 & & & & -0.88 & -2.67 \\
\hline \multirow[t]{2}{*}{ dum_lux } & --- & --- & -0.8493 & -0.4059 & dum_lux & --- & --- & -0.1978 & -0.0928 \\
\hline & & & -4.78 & -2.62 & & & & -4.83 & -2.56 \\
\hline \multirow[t]{2}{*}{ dum_den } & --- & --- & -0.5318 & -0.6208 & dum_den & --- & --- & -0.1237 & -0.1480 \\
\hline & & & -2.96 & -4.66 & & & & -2.99 & -4.75 \\
\hline no. Obs. & 463 & 268 & 487 & 292 & no. Obs. & 463 & 268 & 487 & 292 \\
\hline SSR & 76.6130 & 40.8501 & 62.9743 & 23.3122 & SSR & 3.9071 & 1.2849 & 3.3471 & 1.2752 \\
\hline Log Likeli & -240.5090 & \begin{tabular}{|l|}
-128.2112 \\
\end{tabular} & \begin{tabular}{|c|}
-192.9348 \\
\end{tabular} & -45.2744 & Log Likeli & 448.4260 & 335.3289 & 521.6510 & 378.9790 \\
\hline Prob Chi $^{2}$ & 0.0000 & 0.0000 & 0.0000 & 0.0000 & Prob F & 0.0000 & 0.0000 & 0.0000 & 0.0000 \\
\hline AIC & 1.082 & 1.039 & 0.846 & 0.406 & AIC & -1.894 & -2.420 & -2.089 & -2.500 \\
\hline
\end{tabular}

Note: See Table 1a. 